NBER WORKING PAPER SERIES

CHINESE YELLOW DUST AND KOREAN INFANT HEALTH

\author{
Deokrye Baek \\ Duha T. Altindag \\ Naci Mocan \\ Working Paper 21613 \\ http://www.nber.org/papers/w21613 \\ NATIONAL BUREAU OF ECONOMIC RESEARCH \\ 1050 Massachusetts Avenue \\ Cambridge, MA 02138 \\ October 2015
}

We thank Beom-Cheol Shin at the National Institute of Meteorological Research of Korea and Yujie $\mathrm{Hu}$ for their help with the methodology of the yellow dust measures. Rong Hai, Pablo Peña, Jason M. Hockenberry, Diana Alessandrini, Chris Vickers, Gilad Sorek and Briggs DePew provided useful comments. Jie Zhang provided excellent research assistance. The views expressed herein are those of the authors and do not necessarily reflect the views of the National Bureau of Economic Research.

NBER working papers are circulated for discussion and comment purposes. They have not been peerreviewed or been subject to the review by the NBER Board of Directors that accompanies official NBER publications.

(C) 2015 by Deokrye Baek, Duha T. Altindag, and Naci Mocan. All rights reserved. Short sections of text, not to exceed two paragraphs, may be quoted without explicit permission provided that full credit, including $\odot$ notice, is given to the source. 
Chinese Yellow Dust and Korean Infant Health

Deokrye Baek, Duha T. Altindag, and Naci Mocan

NBER Working Paper No. 21613

October 2015

JEL No. H23,I12,Q51,Q53,Q54

\begin{abstract}
Naturally-occurring yellow sand outbreaks, which are produced by winds flowing to Korea from China and Mongolia, create air pollution. Although there is seasonal pattern of this phenomenon, there exists substantial variation in its timing, strength and location from year to year. Thus, exposure to the intensity of air pollution exhibits significant randomness and unpredictability. To warn residents about air pollution in general, and about these dust storms in particular, Korean authorities issue different types of public alerts. Using birth certificate data on more than 1.5 million babies born between 2003 and 2011, we investigate the impact of air pollution, and the avoidance behavior triggered by pollution alerts on various birth outcomes. We find that exposure to air pollution during pregnancy has a significant negative impact on birth weight, the gestation weeks of the baby, and the propensity of the baby being low weight. Public alerts about air quality during pregnancy have a separate positive effect on fetal health. We show that Korean women do not time their pregnancy according to expected yellow dust exposure, and that educated women's pregnancy timing is not different from those who are lesseducated.The results provide evidence for the effectiveness of pollution alert systems in promoting public health.ШThey also underline the importance of taking into account individuals' avoidance behavior when estimatinglthe impact of air quality on birth outcomes. Specifically, we show that the estimated impact of airlpollution on infant health is reduced by half when the preventive effect of public health warnings is $\llbracket$ not accounted for.
\end{abstract}

\author{
Deokrye Baek \\ Department of Economics \\ Louisiana State University \\ Business education Complex \\ Baton Rouge, LA 70808 \\ econwhite@gmail.com \\ Duha T. Altindag \\ Auburn University \\ Department of Economics \\ 0334 Haley Center \\ Auburn AL, 36849 \\ altindag@auburn.edu
}

\author{
Naci Mocan \\ Department of Economics \\ Louisiana State University \\ 3039 BEC \\ Baton Rouge, LA 70803-6306 \\ and NBER \\ mocan@lsu.edu
}

A data appendix is available at:

http://www.nber.org/data-appendix/w21613 


\section{Chinese Yellow Dust and Korean Infant Health}

\section{Introduction}

It has been documented that health at birth has long term effects on adult health, human capital accumulation and economic well-being. One of the most commonly-used indicators of health at birth is the weight of the infant when she was born. As summarized by Currie (2011) and Almond and Currie (2011), infants who are heavier at birth end up being different in adulthood from those who have lighter birth weights. For example, they are taller adults, have greater IQ scores, attain higher levels of education and earn more when they are adults. Consequently, a sizable literature has investigated the impact on birth weight of its various determinants, ranging from smoking (Lien and Evans 2005, Grossman and Joyce 1990) to prenatal care consumption (Mocan, Raschke and Unel (Forthcoming), Dehejia and LlerasMuney 2004), to nutritional assistance for low-income families (Almond, Hoynes and Schanzenbach 2011).

An important component of this investigation is the extent to which in utero exposure to pollution impacts birth weight. ${ }^{1}$ While the literature on the effect of air pollution on infant mortality is extensive ${ }^{2}$, there are relatively few studies examining the biological effect of pollution on birth weight. Examples of this limited area of inquiry include Currie, Neidell and Schimeider (2009), who show that mother's exposure to carbon monoxide in her last trimester of pregnancy in New Jersey increases the risk of low birth weight. Coneus and Spiess (2012) find a

\footnotetext{
${ }^{1}$ A related research has shown the impact on adult outcomes of in utero exposure to disease and pollution (Black et al. 2013, Sanders 2012, Almond 2006)

${ }^{2}$ Examples include Greenstone and Hanna (2014), Luechinger (2014), Agarwal, Banternghansa and Bui (2010), Jayachandran, (2009), Currie and Neidell (2005), Chay and Greenstone (2003).
} 
similar effect of air pollution on birth weight using German data. Currie et al. (2015) report that toxic plant openings increase the incidence of low birth weight through their detrimental effect on air pollution within one mile radius. Currie and Walker (2012) demonstrate that the introduction of electronic toll collection on the highways of New Jersey and Pennsylvania reduced automobile emissions, resulting in fewer infants with low birth weight.

In this paper we investigate the impact of air pollution on infant health, measured by birth weight and gestational age of newborns. In contrast to the existing body of work that employed data from the U.S. or some European countries, we focus on a new setting, the Republic of Korea. We utilize the universe of birth certificates between 2003 and 2011, which allow us to analyze more than 1.5 million live births. We exploit the exogenous variation in air pollution, created by a natural phenomenon in South Korea: The Yellow Dust (Hwang-sa in Korean). This is a weather event, originated in the arid lands of Northern China and in the desert regions of Mongolia plateau "under the conditions of high temperature, low humidity, and high wind velocity" (Chun et al. 2001). Winds with abnormally high speed, particularly the Westerlies, ${ }^{3}$ pick up dust and sand particles and carry them to the Korean peninsula. Although there is a seasonal pattern of this phenomenon, there exists substantial variation in its strength and location from year to year. In other words, while the intensity of air pollution due to yellow dust exhibits a seasonal cycle, the amplitude of the cycle varies significantly between the years, along with the timing of the up-and-down swings. For example, Figure 1 displays the average concentration of PM10 (particles with a diameter of 10 micrometers or less) levels by month between 2003 and

\footnotetext{
${ }^{3}$ The Westerlies are winds blowing from West to East, and occur in temperate zones -- in the middle latitudes between 30 and 60 degrees latitude.
} 
2006. ${ }^{4}$ The values reported in Figure 1 are average PM10 levels, aggregated over hourly readings in about 130 weather stations across Korea. While pollution generally rises in the Spring and declines during Summer, the pattern is not systematic, and it exhibits substantial noise from year to year. The same irregularity is observed within a given city as well. We demonstrate, in different ways, that women do not time their pregnancy according to expected Yellow Dust exposure, and that educated women's pregnancy timing is not different from those who are less-educated. Therefore, exposure to the intensity of air pollution exhibits substantial randomness and unpredictability.

An important contribution of the paper is the ability to account for avoidance behavior, and to obtain estimates of the impact of pollution avoidance on birth outcomes. Individuals may take precautionary measures in reaction to temporary increases in pollution by such actions as wearing masks or staying indoors. The biological impact of air pollution on health is underestimated if reductions in the exposure to pollution due to avoidance are not accounted for. The paucity of data prevented most of the existing research from controlling for the avoidance behavior, although there are notable exceptions (e.g. Janke 2014, Moretti and Neidell 2011, Neidell 2009). As summarized by Zivin, Neidell and Schlenker (2011), the provision of public notifications and alerts on environmental hazards is being used increasingly as a tool to generate behavioral responses to mitigate the detrimental effects of exposure.

We utilize various pollution alerts at the local level, issued by Korean authorities, to obtain unbiased estimates of the biological impact of pollution on infant health, as well as to

\footnotetext{
${ }^{4}$ Particulate matter intensity is directly linked to negative health consequences such as lung and heart disease and reduced immune system function (http://www.epa.gov/pm/health.html). When inhaled by the pregnant mother, these particles get into pregnant mother's lungs and into the blood stream, and they may be transferred to the infant.
} 
estimate the improvement of infant health generated by pollution avoidance. ${ }^{5}$ Our paper is the first one to investigate the effectiveness of public air quality alerts on birth outcomes. ${ }^{6}$

In a concurrent paper, using the incidence of yellow dust events in Korea, Jia and $\mathrm{Ku}$ (2015) investigate the effect of pollution on mortality. The authors show that during the months in which Chinese pollution is high, an increase in the number of yellow dust events triggers a rise in deaths due to respiratory and cardiovascular causes, especially in the elderly population in Korean districts. Our paper is different from Jia and $\mathrm{Ku}$ (2015) in a number of ways. First, we focus on infant birth outcomes, rather than aggregate mortality. Second, we employ micro data, as opposed to district-level data. Finally, Jia and $\mathrm{Ku}$ (2015) consider neither the avoidance behavior of Koreans nor the public alerts against poor air quality.

We find that, controlling for temperature and precipitation, exposure to air pollution during pregnancy has a significant negative impact on birth weight, gestation weeks of the baby, and the propensity of the baby being low weight (less than 2,500 gr). Public notifications about air quality have a separate statistically significant and positive effect on fetal health. We show that mothers do not time their pregnancy around expected yellow dust exposure, and that educated women's pregnancy timing is not different from those who are less-educated. We also show that white collar families and more educated and older mothers are more likely to give birth in high-pollution cities. These family attributes and the housing price index of the city in which the birth took place are correlated with birth outcomes, but adjusting for these factors does not impact the results appreciably.

\footnotetext{
${ }^{5}$ Neidell (2009), Moretti and Neidell (2011) implement a similar approach when analyzing the impact of ozone on respiratory-related hospitalizations, and asthma.

${ }^{6}$ Janke (2014), Moretti and Neidell (2011), Neidell (2009) and Neidell (2004) also consider public warnings, but these papers focus on the effects of smog and ozone alerts on respiratory illnesses such as the asthma in the general population, rather than birth outcomes.
} 
Our results provide evidence for the effectiveness of pollution alert systems in promoting public health. They also underline the importance of taking into account individuals' avoidance behavior when estimating the impact of air quality on birth outcomes. Specifically, we show that the estimated impact of air pollution on infant health is reduced by half when the preventive effect of public health warnings is not accounted for. Using the regression results, and following the framework of Moretti and Neidell (2011), we obtain estimates of the willingness to pay to reduce air pollution and the cost of the avoidance behavior.

The rest of the paper is organized as follows. In section II we provide a detailed description of the public alert system that is designed to inform people about the yellow dust activity. Section III presents the empirical specification. Section IV describes the conceptual framework on cost of pollution avoidance and willingness to pay. Section V presents the data. Section VI contains the results, robustness analyses and extensions. Section VII discusses the estimates of the cost of avoidance and Section VIII concludes.

\section{Yellow Dust, Air Pollution, and Pollution Alerts}

Yellow Dust is a weather phenomenon originated in Northern China and in the deserts of the Mongolia plateau. High winds pick up particles of dust and sand and carry them towards the Korean peninsula. These particles of dust and sand settle in Korea and they elevate the ambient air pollution, measured by PM10 concentration. This phenomenon generally occurs from March to May, but also irregularly during the winter months. These dust and sand particles are 
detrimental to human health and they have adverse respiratory health effects, particularly in children and the elderly (Ministry of Environment of Korea, 2002). ${ }^{7}$

To reduce the risk of the yellow dust exposure, the Korean government has developed a warning system with behavioral guidelines. Since 2002, Korea Meteorological Administration (KMA) has been releasing notifications to the public based on the measured PM10 levels. Between mid-2002 and 2007, KMA issued an Advisory in a city when the PM10 level was predicted to rise above 500 and $1000 \mu \mathrm{m} / \mathrm{m}^{3}$ for over 2 hours in a day. A Warning was issued when the PM10 level was predicted to rise above $1000 \mu \mathrm{m} / \mathrm{m}^{3}$ for over 2 hours. In February 2007, these thresholds were reduced to 400 and $800 \mu \mathrm{m} / \mathrm{m}^{3}$, respectively. These public notifications advise individuals, especially children, the elderly, and people with respiratory illnesses to limit outdoor activities, and staying indoors is recommended. Pregnant women are suggested to refrain from outdoor activities and to wear protective masks if necessary.

In addition to Warnings and Advisories, officials may declare a Yellow Dust Event (YDE) in the city if ambient yellow dust is noticeable in the air at least once at any time during a day. This is produced daily by specially trained observers in monitoring stations who take into account conditions such as visibility distance, atmospheric turbidity, dust stacks, and odor of the air. Although YDEs are correlated with PM10 concentrations, they are monitored separately from PM10 levels. Because of the health hazards associated with YDEs, YDEs are routinely forecasted by the KMA. These forecasts, similar to weather forecasts, are announced to the public.

\footnotetext{
${ }^{7}$ Epidemiological literature has identified negative health consequences of yellow sand (Park et al. 2005, Lee, Son and Cho 2007).
} 
Anecdotal evidence suggests that individuals tend to consider seriously the information provided by these alerts. For example, as documented by international media, during a Yellow Dust Event, Koreans respond by wearing preventive masks and staying indoors. ${ }^{8}$ For example, in 2002, in response to a particularly high-density yellow dust event elementary schools were closed and plants in some industries, such as semiconductor manufacturing, were temporarily shut down. ${ }^{9}$ Later in the paper we provide evidence that people avoid outdoor activities in response to Advisories, Warnings and YDEs, by demonstrating that attendance to professional soccer games is substantially impacted by these alerts.

\section{Empirical Specification}

To investigate the impact of air pollution and the role of the public alerts on infant health outcomes, we estimate the equation depicted below:

$$
\text { (1) } \text { Health }_{i c t}=\beta_{1} P M 10_{i c t}+\text { Alerts }_{i c t} \boldsymbol{\beta}_{\mathbf{2}}+\beta_{3} Y D E_{c t}+\boldsymbol{X}_{\text {ict }} \boldsymbol{\beta}_{\mathbf{4}}+\boldsymbol{W}_{\text {ict }} \boldsymbol{\beta}_{\mathbf{5}}+\mu_{c}+\theta_{t}+\epsilon_{i c t}
$$

where Health $h_{i c t}$ indicates a particular birth outcome of infant $i$ born to a mother residing in city $c$ on day t. We consider five outcome variables: birth weight in grams, a binary indicator of low birth weight (equals to one if the infant's birth weight is less than 2,500 grams), gestation weeks, an indicator for premature birth (whether infant's gestational age is fewer than 37 weeks), and fetal growth (birth weight per gestation week). ${ }^{10}$ The Korean birth certificate data released to us do not include the exact birthday, but they have information on birth month. We assign the $15^{\text {th }}$

\footnotetext{
${ }^{8}$ The influence of Chinese Yellow Dust on Korea is frequently covered by the media. An example is a piece in New York Times on April $12^{\text {th }}, 2002$, p.3. "China's Growing Deserts Are Suffocating Korea"

$<$ http://events.nytimes.com/2002/04/14/international/asia/14KORE.html?pagewanted=print\&position=top\&_r=0 $>$. CNN also covered the issue on February $23^{\text {rd }}, 2015$ "Yellow dust blankets Seoul"

$<$ http://www.cnn.com/videos/world/2015/02/23/lok-hancocks-south-korea-yellow-dust.cnn>.

${ }^{9} \mathrm{http} / / /$ web.kma.go.kr/aboutkma/biz/asiandust02.jsp

${ }^{10}$ Studies, such as Coneus and Spiess (2012), also used fetal growth as a birth outcome measure.
} 
day of the month as the birthday to each child. Because the birth certificate data include information on gestation in weeks, the day of conception can be determined. Using this information, and assuming that the mother spent her pregnancy in the same city as the one in which she gave birth, her exposure to air pollution during each day of her pregnancy can be determined. We measure air pollution by calculating the PM10 level in each city using hourly readings of all monitoring stations in that city, and by creating a daily average PM10 level for each city. In Equation (1), $P M 10_{i c t}$ is the average hourly exposure to air pollution of infant $i$ 's mother throughout the duration of her pregnancy that ended with the birth of the child on day $t$ in city $c$.

The vector $\boldsymbol{A l e r t s}_{\boldsymbol{i c t}}$ represents the two variables that measure the total number of days in which a public notification is issued in mother's city of residence during her pregnancy that ended at time $t$. There are two types of public alerts: Advisories (issued when PM10 level is anticipated to increase above $500 \mu \mathrm{m} / \mathrm{m}^{3}$ [400 since 2007]) and Warnings (issued when PM10 level is anticipated to increase above $1,000 \mu \mathrm{m} / \mathrm{m}^{3}$ [800 since 2007]). We also include in the regressions the number of days a yellow dust event is observed in mother's city during her pregnancy. This is denoted by $Y D E_{i c t}$ in equation (1).

To investigate potentially differential effects of pollution and that of avoidance behavior on birth outcomes during different developmental stages of the fetus, in some specifications we examine the effect of PM10 and pollution alerts by trimester of pregnancy.

The vector $\boldsymbol{X}$ stands for control variables that include parental characteristics such as the age, education, marital status and employment status of both mother and the father. These attributes are important to control for because they may impact health outcomes. For example, more educated mothers are better producers of infant health (Chou et al. 2010, McCrary and 
Royer 2011) and these attributes may also be correlated with exposure to pollution (e.g. more educated mothers may be more effective in avoiding pollution, or in timing their pregnancy). While we have no income information on birth certificates, parental education is expected to be correlated with family income.

Vector $\boldsymbol{X}$ also contains other variables that impact infant's birth weight (Currie 2011), including infant's gender, an indicator of whether the infant was part of a multiple birth, and birth parity. $\boldsymbol{W}$ is a vector of weather controls such as the average precipitation and temperature during the mother's pregnancy. All regressions include indicators for the city of residence, $\mu_{c}$ to account for unobserved (to us) time-invariant characteristics of cities such as the extent of economic development, urbanization and access to health care. Equation (1) also contains a vector of year-of-conception and month-of-conception dummies, represented by $\theta_{t}$. Standard errors are clustered at the city level.

Anecdotal evidence suggests that Koreans try and reduce/avoid outdoor activities during a yellow dust event (YDE). In order to investigate this point more rigorously, we estimate the effect of YDEs and public alerts on an outdoor activity: attendance to professional soccer games. Soccer games are played in open air stadiums, and if Koreans attempt to avoid pollution when a public alert is issued, then we expect the attendance to a soccer game to decline when a pollution alert is released on the game day. To test this hypothesis, we estimate an equation similar to Zivin and Neidell (2009)

$$
\text { Attendance }_{g c t}=\alpha_{1} P M 10_{c t}+\boldsymbol{A l e r t s}_{c t} \boldsymbol{\alpha}_{2}+\alpha_{3} Y D E_{c t}+\boldsymbol{X}_{\text {gct }} \boldsymbol{\beta}_{\mathbf{4}}+\mu_{c}+\theta_{t}+\epsilon_{g c t}
$$

where Attendance gct $_{\text {is }}$ the number of fans (or the logarithm of fans) who attended a particular soccer game $g$ that took place in city $c$ on day $t . P M 10_{c t}$ is the average PM10 level in city $c$ that 
same day. Alerts $_{\boldsymbol{c t}}$ is the same vector of indicators that take the value of one if an advisory or a warning is issued on the day of the game, as explained above. Similarly, $Y D E_{c t}$ is a dummy variable that is equal to one if a yellow dust event is observed. In vector $\boldsymbol{X}_{\boldsymbol{g c t}}$ we include variables that are likely related to soccer game attendance. For example, games in which high quality teams are playing may attract greater attendance. To control for the quality of the teams, we employ teams' rankings in the league as of the game day. In addition, we control for the round of the game in the tournament. $\mu_{c}$ and $\theta_{t}$ are city fixed effects and time dummies (monthyear).

\section{Cost of Avoidance and Willingness to Pay}

Exposure to air pollution, measured by PM10, has a direct biological impact on birth weight. Public alerts, triggered by air pollution, are expected to generate avoidance; and avoidance impacts birth weight positively. Therefore, an increase in PM10 affects birth weight both directly and indirectly. Thus, holding constant other determinants of birth weight (BW), the total derivative of $B W$ with respect to $P M 10$ is given by equation (3):

$$
\frac{d B W}{d P M 10}=\frac{\partial B W}{\partial P M 10}+\frac{\partial B W}{\partial A v o i d} \frac{\partial A v o i d}{\partial A l e r t} \frac{\partial A l e r t}{\partial P M 10}
$$

The first term on the right hand side of Equation (3) represents the biological health effect of PM10. The second term is the effect on birth weight of PM10 through alerts and avoidance behavior. Following Moretti and Neidell (2011) and the literature they cite, the willingness to pay (WTP) for a reduction in pollution can be expressed as

(4) $\quad W T P=\frac{\partial B W}{\partial P M 10} \times B$ 
where $B$ is the economic benefit associated with a one-gram increase in birth weight. Following Currie, Neidell and Schimeider (2009), we use the estimate provided by Black, Devereux and Salvanes (2007) in approximating B. Specifically, we consider the increase in lifetime earnings due to the increase in birth weight as an estimate of B. The term $\left(\frac{\partial B W}{\partial P M 10}\right)$ in equation (4) is the direct biological effect of pollution on birth weight. The coefficient $\beta_{1}$ in Equation (1) is an estimate of $\frac{\partial B W}{\partial P M 10}$ because the regression in Equation (1) controls for the impact of avoidance (Advisories, Warnings and Yellow Dust Events). Thus, the estimate of the WTP in Equation (4) provides the loss associated with the decline in infant health due to an increase in PM10.

Re-writing equation (3) and multiplying both sides with $B$ yields Equation (5):

$$
\frac{\partial B W}{\partial P M 10} \times B=W T P=\left(\frac{d B W}{d P M 10} \times B\right)-\left(\frac{\partial B W}{\partial A v o i d} \frac{\partial A v o i d}{\partial A l e r t} \frac{\partial A l e r t}{\partial P M 10} \times B\right)
$$

Equation (5) decomposes the willingness to pay (WTP) into two components. The first component includes the term $\frac{d B W}{d P M 10}$ which is the total derivate of birth weight with respect to PM10. This term can be estimated by the coefficient of PM10 using the regression Equation (1), if the regression does not control for variables that are related to avoidance behavior. That is, to the extent that pollution alerts and notifications in Equation (1) capture the factors that influence the demand for avoidance, omitting these variables from equation (1) allows the coefficient of PM10 to represent the total effect of PM10 on birth weight, $\left(\frac{d B W}{d P M 10}\right)$.

Given that one can calculate WTP, as well as the first component of WTP on the righthand side of Equation (5), the second term of WTP $\left(\frac{\partial B W}{\partial A v o i d} \frac{\partial A v o i d}{\partial A l e r t} \frac{\partial A l e r t}{\partial P M 10} \times B\right)$ can be recovered. This last term represents the cost of pollution avoidance (Moretti and Neidell 2011). As 
discussed by Neidell (2009), providing estimates on the cost of pollution avoidance is critical in the assessment of full cost environmental pollution and the design of policy.

\section{Data}

Our data set is compiled from multiple sources. We have information on all births in Korea between 2003 and 2011, obtained from Vital Statistics-Natality Files provided by Statistics Korea Micro Data Service System. Birth certificates provide information about the infant (such as gender, birth weight, gestational length, whether the infant was singleton, and the birth order) and about the parents (such as their age, education level, employment status, and marital status). In addition, the month, year and the city of the birth are reported. Following Knittel, Miller and Sanders (2011), we restrict our sample to infants whose gestational age is between 27 and 42 weeks in order to accurately determine the three trimesters of the pregnancy. In our regressions, we only consider the singleton births, since birth weight differences in twins are largely attributable to biological factors attributable to the mother (Almond, Chay and Lee 2005).

We augment the birth certificate data with data on city air quality, yellow dust events, public notifications and weather conditions. To proxy for air quality, we use PM10 concentration which is measured hourly by the monitoring stations in cities. ${ }^{11}$ These PM10 data are obtained from National Institute of Environmental Research (NIER) in Korea. The variable PM10 is the average hourly PM10 concentration in the city of residence of the mother during her

\footnotetext{
${ }^{11}$ PM10 stands for particulate matter 10 . These are tiny objects in the air that are less than or equal to 10 micrometers in size.
} 
pregnancy. ${ }^{12}$ Figure 2 shows the average daily PM10 concentrations in each region across Korea between years 2003 and 2011 in our sample. ${ }^{13}$ PM10 concentration is relatively higher in the North, in cities close to Northern China and the Mongolia plateau. For example, average PM10 was $58.6 \mu \mathrm{m} / \mathrm{m}^{3}$ in Seoul between 2003 and 2011, whereas Geoje-si, the most-Southeastern region used in our sample, had 36.3 Geoje-si $\mu \mathrm{m} / \mathrm{m}^{3}$. We show later in the paper that the results do not change when we estimate models by geographical location. An important issue is the timing of the pregnancy around the yellow dust season. We show that mothers do not time their pregnancy around yellow dust, arguably because there is substantial uncertainty in the intensity of yellow dust phenomenon from year to year. We obtain weather conditions data (precipitation and temperature) from the annual climatological report provided by the Korea Meteorological Administration(KMA).

Although there are about 4 million births between 2003 and 2011, our estimation sample contains over 1.5 million of these births because births in most locations cannot be matched reliably with air pollution measures because air quality and weather measures are not measured or not measured consistently in these locations. In addition, some regions such as Jeong-eup in North-Jeolla Province are excluded at the advice of the Korea Meteorological Administration because of the inaccuracy of the yellow dust outbreak indicators in those areas.

The descriptions and the summary statistics of the variables are presented in Table $1 .{ }^{14}$ The average Korean infant was born just above 3,200 grams with gestational age of 39 weeks. ${ }^{15}$

\footnotetext{
${ }^{12}$ The birth certificates data set only includes month and year of birth, but not day of birth. In our analysis, we assumed that infants are born on the 15th day of the month reported in the certificate.

${ }^{13}$ Although PM10 concentrations are available at the weather station level in a region, for eight regions (Seoul, Busan, Daegu, Incheon, Gwangju, Daejeon, Ulsan, and Gyeonggi-do) we report the average PM10 levels in a region in this map due to the lack of space.

${ }^{14}$ Our sample period starts in 2003 since dust alert systems were established around the middle of the year 2002. In the data set we obtained from the Statistics Korea, there are about 4 million birth certificates between 2003 and 2011. However, we lose observations since the PM10 data are not available for some Korean cities. The birth
} 
Approximately, three and a half percent of Korean infants are classified as low birth weight $(<2,500$ grams at birth), and four percent of the infants were born premature (gestational age $<37$ weeks). Thirty percent of Korean mothers and 95 percent of fathers are employed. Sixty-six percent of mothers and 70 percent of fathers have a college education or higher.

Average hourly PM10 exposure of a mother during pregnancy is about $54 \mu \mathrm{m} / \mathrm{m}^{3}$. Due to yellow dust breaks, mothers experienced about 1.7 Advisories and 0.5 Warnings during pregnancy. The average Korean mother experienced 7 Yellow Dust Events.

To investigate whether Koreans respond to public notifications of yellow dust events and poor air quality by avoiding outdoors activities, we estimate these notifications' effect on attendance to soccer games played in Korean premier soccer league: K League. These data are obtained from the English version of the official website of the K League. ${ }^{16}$ From this website, we scraped information about the number of people who attended a particular game, the final score, and the teams' performance in the league (standings table). The attendance data span the period between 2004 and 2011. The average attendance to a game during this time period is about 12,500 .

\section{Results}

The Effect of Air Quality, Pollution Alerts and Yellow Dust Events on Birth Outcomes

The results obtained from estimating Equation (1) are presented in Table 2. In addition to the variables listed, all regressions include city fixed effects and year-of-conception and month-

outcomes and parent characteristics of infants that are out of sample are similar to those that enter into our regressions (Appendix Table 1).

${ }^{15}$ In comparison, the average birth weight of U.S. born babies is 3320 grams (Mocan et al. 2013).

${ }^{16} \mathrm{http}: / /$ www.kleague.com/eng 
of-conception fixed effects. Outcome variables are the birth weight in grams (column 1), an indicator for whether the birth weight is less than 2,500 grams (column 2), gestational age in weeks (column 3), an indicator for whether infant's gestational age is less than 37 weeks (column 4), and ratio of birth weight to gestational age (column 5). Standard errors, reported in parentheses, are clustered at the city level.

Column 1 of Table 2 shows that infants born to mothers who were exposed to greater daily PM10 levels (worse air quality) during their pregnancy are born with lower weights. Specifically, a one $\mu \mathrm{m} / \mathrm{m}^{3}$ increase in average exposure to PM10 during pregnancy leads to about 0.8 gram reduction in newborn's birth weight. This indicates that a 10 percent increase in the average hourly PM10 exposure reduces birth weight by about $0.13 \%$ (from the baseline of 3,257 grams), which implies an elasticity of birth weight with respect to PM10 of about 0.013 . $^{17}$

The results of column (1) in Table 2 also indicate that each additional pollution Advisory and Warning that a mother experiences during her pregnancy improves infant's birth weight by 4.4 and 13.6 grams, respectively. A warning's effect is larger than an advisory's effect (p-value < 0.01). This could be because a Warning provides a stronger signal about the dust level than an Advisory, and therefore a warning is associated with stronger health risk and may prompt a stronger avoidance response. The coefficient of Yellow Dust Events in column 1 indicates that each additional day a yellow dust event is issued during pregnancy increases birth weight of the infant by about 8.6 grams. These positive estimates are consistent with the hypothesis that Korean mothers avoid/reduce outside activities when an air quality alert is issued or when there is a yellow dust event in the city of residence of the expecting mother.

\footnotetext{
${ }^{17}$ The elasticity is calculated as $\frac{\partial B W}{\partial P M 10} \div \frac{\overline{B W}}{\overline{P M 10}}=0.8 \times \frac{54.27}{3256}=0.013$.
} 
Similar to those in column (1), the results presented in columns (2)-(5) in Table 2 provide evidence for the detrimental effect of PM10 exposure and the beneficial effect of pollution alerts and yellow dust events on birth outcomes. Each Advisory, Warning and Yellow Dust Event reduces the probability of low birth weight by $0.2,0.5$ and 0.3 percentage points (from the sample mean of 3.4 percentage points), respectively. Similarly, advisories, warnings and yellow dust events increase the gestational age of the infant, probability of premature birth and its average fetal growth, while a rise in PM10 exposure reduces them.

The signs of the control variables in Table 2 are consistent with expectations. Girls and babies born to mothers who have not previously given birth weigh less at birth compared to boys and babies born to mothers who have given birth to at least one baby, respectively. Infants whose parents are employed and have attained higher education levels are born healthier.

Previous papers provide evidence for differential effect on birth outcomes of external factors in different developmental stages of the fetus (Currie 2011). To investigate this possibility, we include in the regressions the exposure to PM10 and the number of alerts against poor air quality during the first, second and third trimesters of pregnancy (instead of the overall exposure during the whole pregnancy). For example, instead of the variable Advisories, we include Advisories - trimester 1, Advisories - trimester 2 and Advisories - trimester 3 that decompose the number of advisories a pregnant woman has experienced during her pregnancy into its first, second and third trimester components. The results, presented in Table 3, are similar to those in Table 2. The number of Advisories, Warnings and Yellow Dust Events experienced in any trimester has a positive and significant impact on birth weight. These effects are not statistically different from each other. An increase in PM10 exposure in the third trimester worsens birth outcomes. Average PM10 exposure in late stages of pregnancy (third trimester) 
has a larger negative impact on the birth outcomes compared to its effect in the first- or secondtrimesters. This finding is consistent with that of Currie, Neidell and Schmieder (2009) who report that exposure to pollution during the third trimester has a more significant impact than exposure during the two earlier trimesters.

The Estimates of Pollution on Birth Outcomes When Avoidance is Omitted

The results in Tables 2 and 3 indicate that mothers' exposure to PM10 is detrimental to the infants' health, while air quality alerts and yellow dust events are beneficial as they allow the pregnant women to avoid pollution. That is, advisories and warnings help pregnant women avoid harmful effects of pollution. Pollution advisories and warnings are issued based on anticipated PM10 concentrations, and elevated PM10 level triggers these notifications. Similarly, Yellow Dust Events cause an increase in ambient PM10 levels. In other words, PM10 levels are positively correlated with the intensity of pollution alerts issued by the government. Given that people take precautions when these warnings are issued, the failure to control for pollution warnings and advisories would bias downwards the estimated biological impact of air pollution.

In Table 4 we report the results of the models that exclude pollution alert indicators. These are the same models as shown in Equation (1), but the variables Advisories, Warnings and Yellow Dust Events are omitted. Put differently, Table 4 is similar to Table 2, except for the pollution alert variables. The coefficients of PM10 in columns (1)-(5) of Table 4 indicate that PM10 is harmful for infants' birth outcomes as shown earlier. However, the magnitude of the impact is much smaller in absolute value when compared to those in Table 2. For example, according to the results in column 1 of Table 4 (where public notifications and yellow dust events are omitted), a one $\mu \mathrm{m} / \mathrm{m}^{3}$ increase in the average exposure to PM10 during pregnancy 
leads to about 0.2 gram reduction in the newborn's birth weight. This same effect is estimated to be 0.8 grams when the full set of control variables is included in the regressions (Column 1 in Table 2). Thus, a comparison of PM10 coefficients between Tables 2 and 4 reveals that the inability to account for the beneficial effect of pollution warnings on health generates a substantial underestimation of the negative impact of pollution on health.

The Impact of Air Quality, Pollution Notifications and Yellow Dust Events on Attendance to Soccer Games

Our results show that air pollution alerts in terms of Advisories, Warnings and Yellow Dust Event notifications are beneficial to birth weight and gestational age. These findings are consistent with the hypothesis that mothers avoid/reduce outdoors activities when a public air quality alert is issued or when a yellow dust event is observed. Ideally, we would like to test this hypothesis using data on the amount of time pregnant mothers spend outside. No such data, however, are available. Instead, we use data on another outdoors activity: attendance to professional soccer games. Soccer games are played in open air stadiums, and the attendees are exposed to air pollution. If Koreans try to avoid pollution when an air pollution notification is announced, then the number of fans who attend a soccer game should decrease when a pollution alert is issued on the game day. To estimate the effect of YDEs and alerts on attendance to the soccer games, we run the regression depicted by equation (2).

Table 5 presents the results obtained from equation (2) where the unit of observation is a soccer game played between two teams of the Korean premier league, K League. The outcome variable is the number of individuals who attended the game. We control for various attributes of the games, including the strength of both teams (approximated by their rank that week), the 
number of goals scored that far during the season, the week of the season, and whether the game is played during the day or at night and in weekdays or at the weekend. We also add stadium fixed-effects, time dummies (month and year), and indicators for the team match-ups. Standard errors are clustered at the stadium level.

In Table 5, the coefficients of Yellow Dust Events and Warnings are negative and significant, lending support to the hypothesis that individuals avoid spending time outside during days of pollution warnings and yellow dust events. Specifically, if a yellow dust event occurs on game day, about 3,400 fewer individuals attend that particular game. This corresponds to about 26 percent decline (from the baseline of 12,500 spectators). Similarly, a Warning on the game day reduces the game attendance by about 7,000.

\section{A Falsification Test}

Neither exposure to pollution, nor avoidance of pollution should impact birth outcomes if pollution is measured after the birth of the infant. To operationalize this idea as a falsification test, we estimated equation (1) using future values of PM10, air quality alerts, and yellow dust events as explanatory variables. Specifically, we ran the regression below:

$$
\text { Health }_{i c t}=\beta_{1} P M 10_{i c t+k}+\text { Alerts }_{i c t+k} \boldsymbol{\beta}_{2}+\beta_{3} Y D E_{i c t+k}+\boldsymbol{X}_{i c t} \boldsymbol{\beta}_{\mathbf{4}}+\mu_{c}+\theta_{t}+\epsilon_{i c t}
$$

where subscript $t+k$ indicates $k$ days after the delivery of the baby at time $t$.

The results obtained from estimating equation (6) are presented in Table 6 where the outcome variable is infant's birth weight. ${ }^{18}$ Columns (1) to (4) pertain to $\mathrm{k}=30,60,90$ and 120 days. For example, in column (1) of Table 6, the rows PM10, Advisories, Warnings, and Yellow

\footnotetext{
${ }^{18}$ Similar results are obtained when other outcome variables are used in the regressions.
} 
Dust Events stand for the corresponding variables measured during the 30 days subsequent to the delivery of the baby. In column 2, these rows indicate the air quality and notification during 60 days following the baby's birth. The full set of control variables, as in Table 2, is included in all regressions. As expected, results show that mother's exposure to poor air quality or her avoidance behavior due to notifications after she delivered the baby does not have any influence of the baby's birth weight.

\section{Other Robustness Checks}

As an extension, to investigate whether air quality and pollution notifications have differential impacts on birth weight, we estimated equation (1) over a number of subsamples. The results are presented in Table 7, where the outcome variable is infant's weight at birth. First, we split the sample into two groups by geographical location. Mothers who live in the North and Northwest Korea could be more responsive to pollution and notifications. The Northern part of Korea is closer to China and it is exposed to more frequent yellow dust events. As a result, individuals could be more aware of adverse effects of yellow dust and poor air quality, and they may respond more intensely. However, the results in columns 1 and 2 of Table 7 suggest the effects of PM10, air quality notifications and yellow dust events on birth weight are similar in both samples. Similarly, there is no difference between mothers who live in cities with poor versus high air quality (PM10 greater or smaller than the median) regarding the effect of air quality and notifications on birth weight (columns 3 and 4).

A potential concern is selection due to unobservables related to mother's health knowledge. For example, pregnant mothers who are more knowledgeable about the detrimental impact of poor air quality may take better preventive action against pollution. They may move 
away from cities of low air quality, or they may time the birth to avoid exposure to high levels of PM10. Alternatively, they may be better at following the advisories and warnings. In that case, our baseline results in Table 2 may be overestimates of the true effect of pollution.

To investigate this possibility, we first estimated equation (1) in subsamples that are separated by mother attributes: mother's education, work experience, and pregnancy experience. Mothers with more education or more experience in the labor market are likely to command more know-how about reducing/eliminating harmful effects of air pollution. Similarly, a mother who has given birth before could be more knowledgeable compared to her counterparts who are expecting their first babies. The results, presented in columns (5) to (10) of Table 7, suggest that our baseline findings are not driven by certain types of mothers. For example, advisories, warnings and yellow dust events improve birth weights of infants born to high-educated or experienced mothers as much as they improve birth weights of low-educated or inexperienced mothers' babies. Similarly, exposure to PM10 is detrimental to infants of high-educated or experienced mothers as much as it is damaging to the health of babies born to low-educated or inexperienced mothers.

As another robustness check, we investigated whether high-educated parents alter the timing of their pregnancies in order to select themselves out of poor air quality seasons. First, using each birth as the unit of observation, we regressed total exposure to pollution during the pregnancy of the mother (measured by PM10) on monthly dummies for the month of conception $(\mathrm{n}=1,549,376)$. This regression showed that PM10 exposure during pregnancy is lower if conception is between the months of March and June. We then created a dummy variable for each mother to indicate if her conception of pregnancy was during this more favorable period (March to June). We ran this Conception Timing dummy on mother's and father's education 
(dummy indicators of having high school education, and having college education as used in all regressions). The results showed that neither mother's nor father's education had any impact on the timing of pregnancy. ${ }^{19}$ Thus, we could not find support for the hypothesis that educated parents adjust the time of their pregnancies to avoid poor air quality.

To investigate any overall seasonal pattern in conceptions, we calculated the total number of conceptions by month in the country and regressed them on 11 monthly dummies to analyze whether the number of conceptions rises or declines in certain months of the year (possibly to avoid pollution). The estimated monthly coefficients and the corresponding confidence intervals are reported in Figure 3. In no case the coefficients are different from zero, signifying that the number of conceptions does not exhibit any seasonal pattern.

\section{Residential Location Decision}

A possible bias in our estimates could emerge due to the geographical selection of parents. For example, if families with more income and higher education reside in bigger cities with worse ambient air quality, and if such families have high productive and/or allocative efficiency in infant health production (Grossman 2008 and 1972, Rosenzweig and Schultz 1982, Kenkel 1991, Altindag, Cannonier and Mocan 2011), then the negative impact of pollution on birth outcomes is underestimated.

To investigate the correlation between city-level air pollution and parent attributes, we estimated a regression where the outcome variable is an indicator that takes the value of one if the infant is born in a city where average PM10 level is above the national median. ${ }^{20}$ The

\footnotetext{
${ }^{19}$ The point estimates ranged from -0.005 to 0.0007 with p-values ranging from 0.15 to 0.81 .

${ }^{20}$ This is the variable that we use to divide the sample into two (columns 3 and 4 ) in Table 7.
} 
explanatory variables included parent characteristics and month- and year-of conception dummies. In addition, the variable White Collar Family took the value of one if both mother and father have white collar jobs such as managers, engineers and office workers. Families for which White Collar Family is zero include at least one parent with a blue collar job (such as laborer, technician) or an agricultural job. The results presented in column (1) of Table 8 indicate that mothers who delivered their baby in high pollution cities are more likely to be working, older, married and slightly more educated. Also, those mothers are delivering their first infant. Father characteristics are unrelated to the probability of the child being born in a high pollution city. In column (2) of Table 8, the coefficient of White Collar Family is positive indicating that infants whose parents have white collar jobs are more likely to be born in more polluted cities. Thus, the results of Table 8 support the hypothesis that parents with potentially higher incomes select into more polluted cities. To the extent that such families are more efficient in the production of infant health, the negative impact of pollution on infant health could be underestimated. In this case, our baseline result presented in Tables 2-4 represent an underestimate of the effect of PM10 on infant health.

To investigate this issue, we augmented the regression depicted in equation (1) with two variables that are shown to be related to air pollution in the city at the time of the birth (Table 8) as well as potentially correlated with productive/allocative efficiency of the family. The first variable is White Collar Family as described earlier. We also added the housing price index of the city (Housing Price Index) in which the family resides. Higher housing prices may reflect more favorable city characteristics including better health care services. ${ }^{21}$ The results are

\footnotetext{
${ }^{21}$ We include 9 month lagged Housing Price Index (HPI) to capture city amenities at the time of conception. Using contemporaneous HPI does not change the results.
} 
reported in Panel A of Table $9 .{ }^{22}$ As expected, Housing Price Index is positively correlated with infant health. Similarly infants born to white collar families have better health at birth. The coefficients of PM10, Advisories, Warnings and Yellow Dust Events do not change in any significant way when White Collar Family and Housing Price Index are not controlled for in the regressions (Panel B of Table 9).

\section{The Willingness to Pay and the Cost of Avoidance Behavior}

Conditional on avoidance, the impact of a $10 \%$ increase in PM10 on birth weight $\left(\frac{\partial B W}{\partial P M 10}\right)$ is 4.3 grams (using the coefficient of -0.8 in column 1 of Table 2). This represents a $0.13 \%$ decrease from the baseline average of 3,257 gr. Black, Devereux and Salvanes (2007) report that a one-percent increase in an infant's birth weight generates an increase in future earnings by about $0.13 \%$. An average full time Korean worker's annual earning was about $\$ 28,000$ in $2010 .{ }^{23}$ Assuming the average newborn will earn as much as the average worker, and considering that a typical Korean starts working at age 25 and retires at age 60 (the official retirement age in Korea), and using a discount rate of six percent, the present value of the benefit generated by a $10 \%$ decline in PM10 is about $\$ 20$. This is the estimated value of the Willingness to Pay (WTP), which is depicted by equation (4). In 2010, 470,000 babies were born in Korea. Thus, the full cost of a 10\% increase in PM10 for one cohort of Koreans is $\$ 9.5$ million.

\footnotetext{
${ }^{22}$ Sample size is smaller in these regressions since we lose observations due to lack of HPI data in some cities.

${ }^{23}$ Source: OECD Statistics. http://stats.oecd.org/.
} 
The estimated coefficient of PM10 reported in column (1) of Table 4 corresponds to

$\left(\frac{d B W}{d P M 10}\right)$. This is because the models reported in Table 4 do not control for pollution alerts which shift the demand for avoidance. In this specification, a 10\% increase in PM10 generates a reduction in birth weight by $0.03 \%$; and using the same B as above, this produces a cost of $\$ 2$ million for one cohort of Korean babies. Using Equation (5), this implies that the cost of avoidance is $\$ 7.5$ million (in 2010 dollars). We should note that the benefit value used in this exercise pertains to increased future earnings of the infant, and it does not include any other elements such as health-related expenditures. For example, to the extent that poor health at birth has an impact on chronic health conditions in adulthood, the benefits should be adjusted upwards. Thus, the magnitudes we report should be considered as lower bounds.

\section{Summary and Conclusion}

Previous research has shown that infant health, particularly weight at birth, is an important predictor of future well-being of individuals, including earnings. An important determinant of birth weight is prenatal exposure to pollution. A complicating issue in the investigation of the impact of environmental pollution to infant health is the difficulty in finding exogenous exposure to pollution. Individuals and families who are likely to live in less polluted areas may have better health outcomes because of particular attributes of these families, unrelated to pollution. Such endogenous geographical selection, or endogenous timing of a pregnancy would confound the estimated impact of pollution on infant health. Second, as policy makers increasingly emphasize the relevance of pollution warnings and air quality alerts as a potential tool to modify exposure of individuals through avoidance behavior, it is essential to determine the effectiveness of such alerts. This is important not only because the failure to 
account for avoidance behavior would provide an underestimate of the biological impact of pollution on health, but also because of the significance of the welfare loss associated with such avoidance behavior.

In this paper we investigate the impact of air pollution on infant health using information on more than one and a half million live births in the Republic of Korea. The novelty of our identification strategy is the ability to measure the exposure of pregnant women to pollution generated by a natural phenomenon: the yellow dust. Winds carry particles of dust and sand from the arid lands of Northern China and the deserts of Mongolia to the Korean peninsula. These particles of dust and sand settle in Korea and they elevate the ambient air pollution, measured by PM10 concentration. Although there is a seasonal pattern of this phenomenon, there is significant variation in its timing, strength and location from year to year. Thus, exposure to the intensity of air pollution exhibits substantial randomness and unpredictability. We also show that Korean women do not time their pregnancy according to expected yellow dust exposure, and that educated women's pregnancy timing is not different than those who are lesseducated.

We measure air pollution in each city by calculating the PM10 level, using hourly readings of all monitoring stations in that city, and creating a city-level daily average PM10. Using these daily air pollution data and making use of the gestation weeks reported on birth certificates, we measure the extent of exposure to pollution of each pregnancy.

An important contribution of the paper is the ability to account for avoidance behavior. We utilize pollution advisories, pollution warnings as well as alerts on yellow dust events that are issued by Korean authorities at the local level. We obtain estimates of the biological impact of pollution on infant health, and the improvement in infant health generated by pollution 
avoidance. Our paper is the first one to investigate the effectiveness of pollution alerts on birth outcomes.

The results show that exposure to air pollution during pregnancy has a significant negative impact on birth weight, gestation weeks of the baby, and the propensity of the baby being low weight. Public notifications about air quality have a separate statistically significant and positive effect on infant health. In complementary analysis we show that the same public notifications significantly reduce attendance to professional soccer games, supporting the premise that individuals avoid being outdoors when pollution alerts are issued.

We find white collar families and more educated and older mothers are more likely to give birth in high-pollution cities. These family attributes and the housing price index of the city in which the birth took place are correlated with birth outcomes. Adjusting for these factors, however, does not impact the results.

Our results provide evidence for the effectiveness of pollution alert systems in promoting public health. They also underline the importance of taking into account individuals' avoidance behavior when estimating the impact of air quality on birth outcomes. We show that the estimated impact of air pollution on infant health is reduced by half when the preventive effect of public health warnings is not accounted for. Using future earnings as the only component of the benefit of pollution reduction, our estimates imply that willingness to pay, associated with a $10 \%$ decline in the level of PM10, is $\$ 9.5$ million (in 2010 dollars) for one cohort of babies, and the corresponding cost of avoidance is $\$ 7.5$ million. To the extent that poor health at birth has an impact on health conditions later in life, the magnitudes we report should be considered as lower bounds. 
Table 1: Summary Statistics

\begin{tabular}{|c|c|c|c|}
\hline Variable & Description & Mean & Std. Dev. \\
\hline Birth weight & Baby's weight at birth (grams) & 3257 & 430 \\
\hline Low birth weight & $=1$ if birth weight is less than 2,500 grams. & 0.034 & 0.181 \\
\hline Gestation & Gestational age in weeks & 38.94 & 1.48 \\
\hline Premature & $=1$ if gestation $<37$ weeks & 0.042 & 0.200 \\
\hline Fetal growth & Birth weight/Gestation & 83.54 & 10.20 \\
\hline Advisories & Number of advisories issued during pregnancy & 1.72 & 1.36 \\
\hline Warnings & Number of warnings issued during pregnancy & 0.51 & 0.59 \\
\hline Yellow dust events & Number of observed yellow dust outbreaks. & 6.77 & 3.80 \\
\hline PM10 & Average daily PM10 during pregnancy & 54.27 & 8.79 \\
\hline Temperature & Average temperature during pregnancy $\left({ }^{\circ} \mathrm{C}\right)$ & 13.43 & 3.00 \\
\hline Precipitation & Average precipitation during pregnancy (mm.) & 125.26 & 46.77 \\
\hline Girl & $=1$ if the baby is a girl & 0.484 & 0.500 \\
\hline Second baby & $=1$ if the baby is mother's second child & 0.376 & 0.484 \\
\hline Third baby & $=1$ if the baby is mother's third, fourth,... etc. & 0.085 & 0.278 \\
\hline Married & $=1$ if baby is born within a marriage & 0.991 & 0.096 \\
\hline Mother working & $=1$ if mother is working & 0.288 & 0.453 \\
\hline Mother's age 20-30 & $=1$ if mother's age is between 20 and 30 & 0.408 & 0.491 \\
\hline Mother's age $30-40$ & $=1$ if mother's age is between 30 and 40 & 0.573 & 0.495 \\
\hline Mother's age $40+$ & $=1$ if mother is older than 40 & 0.015 & 0.122 \\
\hline Mother high school grad. & $=1$ if mother has completed high school & 0.323 & 0.468 \\
\hline Mother college grad. & $=1$ if mother has completed college or more & 0.659 & 0.474 \\
\hline Father working & $=1$ if father is working & 0.954 & 0.210 \\
\hline Father's age $20-30$ & $=1$ if father's age is between 20 and 30 & 0.181 & 0.385 \\
\hline Father's age $30-40$ & $=1$ if father's age is between 30 and 40 & 0.749 & 0.433 \\
\hline Father's age $40+$ & $=1$ if father is older than 40 & 0.069 & 0.253 \\
\hline Father high school grad. & $=1$ if father has completed high school & 0.291 & 0.454 \\
\hline Father college grad. & $=1$ if father has completed college or more & 0.689 & 0.463 \\
\hline
\end{tabular}

Notes: Sample consists of 1,549,376 observations. Unit of observation is newborn baby. 
Table 2: The Effect of Alerts and Air Pollution on Birth Outcomes

\begin{tabular}{|c|c|c|c|c|c|}
\hline & $(1)$ & $(2)$ & (3) & $(4)$ & (5) \\
\hline & Birth Weight & Low Birth Weight & Gestation & Premature Birth & Fetal Growth \\
\hline \multirow[t]{2}{*}{ PM10 } & $-0.798 * * *$ & $0.0003 * * *$ & $-0.004 * * *$ & $0.001 * * *$ & $-0.012 * * *$ \\
\hline & $(0.150)$ & $(0.0001)$ & $(0.001)$ & $(0.000)$ & $(0.003)$ \\
\hline \multirow[t]{2}{*}{ Advisories } & $4.360 * * *$ & $-0.002 * * *$ & $0.037 * * *$ & $-0.004 * * *$ & $0.043 * *$ \\
\hline & (1.007) & $(0.000)$ & $(0.006)$ & $(0.001)$ & $(0.018)$ \\
\hline \multirow[t]{2}{*}{ Warnings } & $13.565 * * *$ & $-0.005 * * *$ & $0.086^{* * *}$ & $-0.007 * * *$ & $0.186^{* * *}$ \\
\hline & (1.488) & $(0.001)$ & $(0.009)$ & $(0.001)$ & $(0.028)$ \\
\hline \multirow[t]{2}{*}{ Yellow dust events } & $8.578 * * *$ & $-0.003 * * *$ & $0.057 * * *$ & $-0.006^{* * *}$ & $0.113 * * *$ \\
\hline & $(0.403)$ & $(0.000)$ & $(0.002)$ & $(0.000)$ & $(0.007)$ \\
\hline \multirow[t]{2}{*}{ Temperature } & $-18.634 * * *$ & $0.005 * * *$ & $-0.148 * * *$ & $0.003 * * *$ & $-0.180 * * *$ \\
\hline & $(1.587)$ & $(0.001)$ & $(0.009)$ & $(0.001)$ & $(0.031)$ \\
\hline \multirow[t]{2}{*}{ Precipitation } & $-0.160 * * *$ & $0.0000 * * *$ & $-0.001 * * *$ & $0.0001 * * *$ & $-0.002 * * *$ \\
\hline & $(0.023)$ & $(0.0000)$ & $(0.000)$ & $(0.0000)$ & $(0.000)$ \\
\hline \multirow[t]{2}{*}{ Girl } & $-97.816^{* * *}$ & $0.007 * * *$ & $0.134 * * *$ & $-0.008 * * *$ & $-2.789 * * *$ \\
\hline & $(0.723)$ & $(0.000)$ & $(0.003)$ & $(0.000)$ & $(0.016)$ \\
\hline \multirow[t]{2}{*}{ Second baby } & $30.726^{* * *}$ & $-0.011 * * *$ & $-0.403 * * *$ & 0.0002 & $1.677 * * *$ \\
\hline & $(1.331)$ & $(0.000)$ & $(0.005)$ & $(0.0004)$ & $(0.031)$ \\
\hline \multirow[t]{2}{*}{ Third baby } & $60.913 * * *$ & $-0.010 * * *$ & $-0.406 * * *$ & $0.006 * * *$ & $2.452 * * *$ \\
\hline & $(2.029)$ & $(0.001)$ & $(0.006)$ & $(0.001)$ & $(0.050)$ \\
\hline \multirow[t]{2}{*}{ Married } & $32.039 * * *$ & $-0.012 * * *$ & $0.111 * * *$ & $-0.012 * * *$ & $0.609 * * *$ \\
\hline & $(4.006)$ & $(0.002)$ & $(0.012)$ & $(0.002)$ & $(0.099)$ \\
\hline \multirow[t]{2}{*}{ Mother working } & $5.525 * * *$ & -0.0005 & -0.002 & 0.0003 & $0.144 * * *$ \\
\hline & $(0.944)$ & $(0.0003)$ & $(0.003)$ & $(0.0003)$ & $(0.022)$ \\
\hline \multirow[t]{2}{*}{ Mother's age $20-30$} & $66.926 * * *$ & -0.005 & $0.048 * *$ & $-0.007 *$ & $1.610 * * *$ \\
\hline & $(6.820)$ & $(0.003)$ & $(0.023)$ & $(0.004)$ & $(0.165)$ \\
\hline \multirow[t]{2}{*}{ Mother's age $30-40$} & $63.824 * * *$ & 0.002 & -0.029 & -0.0001 & $1.670 * * *$ \\
\hline & $(6.871)$ & $(0.003)$ & $(0.023)$ & $(0.0039)$ & $(0.167)$ \\
\hline \multirow[t]{2}{*}{ Mother's age $40+$} & $19.946^{* * *}$ & $0.021 * * *$ & $-0.294 * * *$ & $0.023 * * *$ & $1.064 * * *$ \\
\hline & $(7.198)$ & $(0.004)$ & $(0.027)$ & $(0.004)$ & $(0.177)$ \\
\hline \multirow{2}{*}{$\begin{array}{l}\text { Mother high sch. } \\
\text { grad. }\end{array}$} & $43.048^{* * *}$ & $-0.011 * * *$ & $0.053 * * *$ & $-0.006 * * *$ & $1.006 * * *$ \\
\hline & $(3.311)$ & $(0.002)$ & $(0.012)$ & $(0.002)$ & $(0.077)$ \\
\hline \multirow[t]{2}{*}{ Mother college grad. } & $49.751 * * *$ & $-0.016^{* * *}$ & $0.115 * * *$ & $-0.012 * * *$ & $1.056 * * *$ \\
\hline & (3.499) & $(0.002)$ & $(0.012)$ & $(0.002)$ & $(0.082)$ \\
\hline \multirow[t]{2}{*}{ Father working } & $8.173 * * *$ & $-0.003 * * *$ & -0.004 & $-0.003 * * *$ & $0.235 * * *$ \\
\hline & $(1.598)$ & $(0.001)$ & $(0.006)$ & $(0.001)$ & $(0.037)$ \\
\hline \multirow[t]{2}{*}{ Father's age $20-30$} & $35.193 * * *$ & $-0.019 * *$ & 0.047 & $-0.019 * * *$ & $0.838 * * *$ \\
\hline & $(11.528)$ & $(0.008)$ & $(0.044)$ & $(0.007)$ & $(0.267)$ \\
\hline \multirow[t]{2}{*}{ Father's age $30-40$} & $36.428 * * *$ & $-0.019 * *$ & 0.052 & $-0.019 * * *$ & $0.859 * * *$ \\
\hline & $(11.464)$ & $(0.008)$ & $(0.044)$ & $(0.007)$ & $(0.268)$ \\
\hline \multirow[t]{2}{*}{ Father's age $40+$} & $27.342 * *$ & -0.012 & -0.027 & -0.011 & $0.776^{* * *}$ \\
\hline & $(11.136)$ & $(0.008)$ & $(0.045)$ & $(0.007)$ & $(0.256)$ \\
\hline \multirow[t]{2}{*}{ Father high sch. grad. } & $22.819 * * *$ & $-0.005^{* * *}$ & $0.020 * *$ & $-0.004 * * *$ & $0.541 * * *$ \\
\hline & $(3.012)$ & $(0.001)$ & $(0.009)$ & $(0.001)$ & $(0.072)$ \\
\hline \multirow[t]{2}{*}{ Father college grad. } & $28.774 * * *$ & $-0.010 * * *$ & $0.069 * * *$ & $-0.008 * * *$ & $0.602 * * *$ \\
\hline & $(3.237)$ & $(0.001)$ & $(0.010)$ & $(0.001)$ & $(0.078)$ \\
\hline $\mathrm{N}$ & $1,549,376$ & $1,549,376$ & $1,549,376$ & $1,549,376$ & $1,549,376$ \\
\hline
\end{tabular}

Notes: Outcome variables are baby's weight at birth in grams, an indicator for whether baby's birth weight is less than 2,500 grams, gestation weeks, an indicator for whether infant is born with gestational age less than 37 weeks, and the ratio of birth weight to gestation weeks in columns 1 to 5 , respectively. Regressions include city fixed effects, and time dummies for conception year and month. Standard errors clustered at the city level are presented in parentheses. $*, * *$ and $* * *$ indicate significance at $10 \%, 5 \%$ and $1 \%$, respectively. 
Table 3: The Effect of Alerts and Air Pollution on Birth Outcomes (Trimesters)

\begin{tabular}{|c|c|c|c|c|c|}
\hline & (1) & (2) & (3) & (4) & (5) \\
\hline & Birth Weight & Low Birth Weight & Gestation & $\begin{array}{l}\text { Premature } \\
\text { Birth }\end{array}$ & $\begin{array}{c}\text { Fetal } \\
\text { Growth }\end{array}$ \\
\hline \multicolumn{6}{|l|}{ PM10 } \\
\hline in trimester 1 & $\begin{array}{l}-0.110 \\
(0.090)\end{array}$ & $\begin{array}{l}0.0001 * \\
(0.0000)\end{array}$ & $\begin{array}{c}-0.0002 \\
(0.0007)\end{array}$ & $\begin{array}{c}-0.0000 \\
(0.0001)\end{array}$ & $\begin{array}{c}-0.002 \\
(0.002)\end{array}$ \\
\hline in trimester 2 & $\begin{array}{l}-0.049 \\
(0.092)\end{array}$ & $\begin{array}{c}0.0001 \\
(0.0000)\end{array}$ & $\begin{array}{c}0.0000 \\
(0.0006)\end{array}$ & $\begin{array}{c}0.0001 * * * \\
(0.0000)\end{array}$ & $\begin{array}{c}-0.002 \\
(0.002)\end{array}$ \\
\hline in trimester 3 & $\begin{array}{c}-0.799 * * * \\
(0.110)\end{array}$ & $\begin{array}{c}0.0002 * * * \\
(0.0000)\end{array}$ & $\begin{array}{c}-0.006 * * * \\
(0.001)\end{array}$ & $\begin{array}{c}0.0003 * * * \\
(0.0001)\end{array}$ & $\begin{array}{c}-0.009 * * * \\
(0.002)\end{array}$ \\
\hline \multicolumn{6}{|l|}{$\underline{\text { Advisories }}$} \\
\hline$\overline{\text { in trimester } 1}$ & $\begin{array}{c}4.647 * * * \\
(1.455)\end{array}$ & $\begin{array}{c}-0.002 * * * \\
(0.001)\end{array}$ & $\begin{array}{c}0.042 * * * \\
(0.009)\end{array}$ & $\begin{array}{c}-0.003 * * * \\
(0.001)\end{array}$ & $\begin{array}{c}0.037 \\
(0.026)\end{array}$ \\
\hline in trimester 2 & $\begin{array}{c}12.571 * * * \\
(1.170)\end{array}$ & $\begin{array}{c}-0.006^{* * *} \\
(0.000)\end{array}$ & $\begin{array}{c}0.084^{* * * *} \\
(0.007)\end{array}$ & $\begin{array}{c}-0.009^{* * *} \\
(0.001)\end{array}$ & $\begin{array}{c}0.167 * * * \\
(0.020)\end{array}$ \\
\hline in trimester 3 & $\begin{array}{c}6.427 * * * \\
(1.305)\end{array}$ & $\begin{array}{c}-0.003 * * * \\
(0.001)\end{array}$ & $\begin{array}{c}0.055^{* * *} \\
(0.008)\end{array}$ & $\begin{array}{c}-0.006 * * * \\
(0.001)\end{array}$ & $\begin{array}{c}0.060 * * \\
(0.023)\end{array}$ \\
\hline \multicolumn{6}{|l|}{$\underline{\text { Warnings }}$} \\
\hline in trimester 1 & $\begin{array}{c}13.515 * * * \\
(2.185)\end{array}$ & $\begin{array}{c}-0.004 * * * \\
(0.001)\end{array}$ & $\begin{array}{c}0.093 * * * \\
(0.016)\end{array}$ & $\begin{array}{c}-0.005^{* * *} \\
(0.001)\end{array}$ & $\begin{array}{c}0.167 * * * \\
(0.037)\end{array}$ \\
\hline in trimester 2 & $\begin{array}{c}7.848 * * * \\
(1.896)\end{array}$ & $\begin{array}{c}-0.004 * * * \\
(0.001)\end{array}$ & $\begin{array}{c}0.034 * * * \\
(0.012)\end{array}$ & $\begin{array}{c}-0.010^{* * *} \\
(0.001)\end{array}$ & $\begin{array}{c}0.150^{* * * *} \\
(0.035)\end{array}$ \\
\hline in trimester 3 & $\begin{array}{c}14.982 * * * \\
(1.991)\end{array}$ & $\begin{array}{c}-0.005^{* * *} \\
(0.001)\end{array}$ & $\begin{array}{c}0.097 * * * \\
(0.011)\end{array}$ & $\begin{array}{c}-0.006^{* * * *} \\
(0.001)\end{array}$ & $\begin{array}{c}0.197 * * * \\
(0.037)\end{array}$ \\
\hline \multicolumn{6}{|l|}{ Yellow dust events } \\
\hline in trimester 1 & $\begin{array}{c}8.597 * * * \\
(0.459)\end{array}$ & $\begin{array}{c}-0.004^{* * *} \\
(0.000)\end{array}$ & $\begin{array}{c}0.054 * * * \\
(0.003)\end{array}$ & $\begin{array}{c}-0.006^{* * *} \\
(0.000)\end{array}$ & $\begin{array}{c}0.121^{* * * *} \\
(0.009)\end{array}$ \\
\hline in trimester 2 & $\begin{array}{c}10.935^{* * * *} \\
(0.498)\end{array}$ & $\begin{array}{c}-0.004^{* * *} * \\
(0.000)\end{array}$ & $\begin{array}{c}0.074 * * * \\
(0.003)\end{array}$ & $\begin{array}{c}-0.007 * * * \\
(0.000)\end{array}$ & $\begin{array}{c}0.140 * * * \\
(0.008)\end{array}$ \\
\hline in trimester 3 & $\begin{array}{c}11.778^{* * *} \\
(0.570)\end{array}$ & $\begin{array}{c}-0.004 * * * \\
(0.000)\end{array}$ & $\begin{array}{c}0.083 * * * \\
(0.003)\end{array}$ & $\begin{array}{c}-0.006^{* * *} \\
(0.000)\end{array}$ & $\begin{array}{c}0.142^{* * * *} \\
(0.010)\end{array}$ \\
\hline \multicolumn{6}{|l|}{$\underline{\text { Temperature }}$} \\
\hline in trimester 1 & $\begin{array}{c}6.851 * * * \\
(0.968)\end{array}$ & $\begin{array}{c}0.0000 \\
(0.0005)\end{array}$ & $\begin{array}{c}0.060^{* * *} \\
(0.006)\end{array}$ & $\begin{array}{c}0.005^{* * *} \\
(0.001)\end{array}$ & $\begin{array}{c}0.041 * * \\
(0.018)\end{array}$ \\
\hline in trimester 2 & $\begin{array}{c}-3.228 * * * \\
(0.519)\end{array}$ & $\begin{array}{l}-0.0004 \\
(0.0003)\end{array}$ & $\begin{array}{c}-0.035 * * * \\
(0.003)\end{array}$ & $\begin{array}{c}-0.004 * * * \\
(0.000)\end{array}$ & $\begin{array}{c}-0.002 \\
(0.010)\end{array}$ \\
\hline in trimester 3 & $\begin{array}{c}-8.913 * * * \\
(0.843)\end{array}$ & $\begin{array}{c}0.004 * * * \\
(0.000)\end{array}$ & $\begin{array}{c}-0.056^{* * *} \\
(0.005)\end{array}$ & $\begin{array}{c}0.007 * * * \\
(0.001)\end{array}$ & $\begin{array}{c}-0.128 * * * \\
(0.016)\end{array}$ \\
\hline Precipitation & & & & & \\
\hline in trimester 1 & $\begin{array}{l}-0.004 \\
(0.009)\end{array}$ & $\begin{array}{c}0.0000 \\
(0.0000)\end{array}$ & $\begin{array}{c}0.0002 * * \\
(0.0001)\end{array}$ & $\begin{array}{c}0.0000 * * * \\
(0.0000)\end{array}$ & $\begin{array}{c}-0.0005^{* *} \\
(0.0002)\end{array}$ \\
\hline in trimester 2 & $\begin{array}{c}-0.096^{* * *} \\
(0.009)\end{array}$ & $\begin{array}{c}0.0000 * * * \\
(0.0000)\end{array}$ & $\begin{array}{c}-0.001 * * * \\
(0.000)\end{array}$ & $\begin{array}{c}0.0000 * * * \\
(0.0000)\end{array}$ & $\begin{array}{c}-0.001 * * * \\
(0.000)\end{array}$ \\
\hline in trimester 3 & $\begin{array}{c}0.006 \\
(0.017)\end{array}$ & $\begin{array}{c}0.0000^{* *} \\
(0.0000)\end{array}$ & $\begin{array}{l}0.0002 * \\
(0.0001)\end{array}$ & $\begin{array}{c}0.0001 * * * \\
(0.0000)\end{array}$ & $\begin{array}{c}-0.0003 \\
(0.0003)\end{array}$ \\
\hline Girl & $\begin{array}{c}-97.967 * * * \\
(0.717)\end{array}$ & $\begin{array}{c}0.007 * * * \\
(0.000)\end{array}$ & $\begin{array}{c}0.133 * * * \\
(0.003)\end{array}$ & $\begin{array}{c}-0.008 * * * \\
(0.000)\end{array}$ & $\begin{array}{c}-2.790 * * * \\
(0.016)\end{array}$ \\
\hline
\end{tabular}


Table 3 (concluded)

\begin{tabular}{|c|c|c|c|c|c|}
\hline & (1) & $(2)$ & (3) & $(4)$ & $(5)$ \\
\hline & Birth Weight & $\begin{array}{c}\text { Low Birth } \\
\text { Weight }\end{array}$ & Gestation & $\begin{array}{l}\text { Premature } \\
\text { Birth }\end{array}$ & Fetal Growth \\
\hline Second baby & $\begin{array}{c}31.179 * * * \\
(1.347)\end{array}$ & $\begin{array}{c}-0.011 * * * \\
(0.000)\end{array}$ & $\begin{array}{c}-0.399 * * * \\
(0.005)\end{array}$ & $\begin{array}{c}0.0001 \\
(0.0004)\end{array}$ & $\begin{array}{c}1.682 * * * \\
(0.031)\end{array}$ \\
\hline Third baby & $\begin{array}{c}61.531 * * * \\
(2.035)\end{array}$ & $\begin{array}{c}-0.010 * * * \\
(0.001)\end{array}$ & $\begin{array}{c}-0.401 * * * \\
(0.006)\end{array}$ & $\begin{array}{c}0.006^{* * *} * \\
(0.001)\end{array}$ & $\begin{array}{c}2.458 * * * \\
(0.050)\end{array}$ \\
\hline Mother's age 20-30 & $\begin{array}{c}66.811^{* * *} \\
(6.802)\end{array}$ & $\begin{array}{l}-0.005 \\
(0.003)\end{array}$ & $\begin{array}{c}0.047^{* *} \\
(0.022)\end{array}$ & $\begin{array}{l}-0.007^{*} \\
(0.004)\end{array}$ & $\begin{array}{c}1.609 * * * \\
(0.165)\end{array}$ \\
\hline Mother's age $30-40$ & $\begin{array}{c}63.816^{* * *} \\
(6.866)\end{array}$ & $\begin{array}{c}0.003 \\
(0.003)\end{array}$ & $\begin{array}{l}-0.029 \\
(0.023)\end{array}$ & $\begin{array}{c}-0.0001 \\
(0.0039)\end{array}$ & $\begin{array}{c}1.670 * * * \\
(0.167)\end{array}$ \\
\hline Mother's age $40+$ & $\begin{array}{c}20.213^{* * * *} \\
(7.190)\end{array}$ & $\begin{array}{c}0.021 * * * \\
(0.004)\end{array}$ & $\begin{array}{c}-0.292 * * * \\
(0.027)\end{array}$ & $\begin{array}{c}0.023 * * * \\
(0.004)\end{array}$ & $\begin{array}{c}1.068 * * * \\
(0.177)\end{array}$ \\
\hline Mother high sch. grad. & $\begin{array}{c}43.299 * * * \\
(3.308)\end{array}$ & $\begin{array}{c}-0.011 * * * \\
(0.002)\end{array}$ & $\begin{array}{c}0.054 * * * \\
(0.012)\end{array}$ & $\begin{array}{c}-0.006^{* * * *} \\
(0.002)\end{array}$ & $\begin{array}{c}1.008 * * * \\
(0.078)\end{array}$ \\
\hline Mother college grad. & $\begin{array}{c}49.954 * * * \\
(3.501)\end{array}$ & $\begin{array}{c}-0.016^{* * *} \\
(0.002)\end{array}$ & $\begin{array}{c}0.116 * * * \\
(0.012)\end{array}$ & $\begin{array}{c}-0.012 * * * \\
(0.002)\end{array}$ & $\begin{array}{c}1.059 * * * \\
(0.082)\end{array}$ \\
\hline Father working & $\begin{array}{c}8.188^{* * *} \\
(1.590)\end{array}$ & $\begin{array}{c}-0.003 * * * \\
(0.001)\end{array}$ & $\begin{array}{l}-0.004 \\
(0.006)\end{array}$ & $\begin{array}{c}-0.003 * * * \\
(0.001)\end{array}$ & $\begin{array}{c}0.236 * * * \\
(0.037)\end{array}$ \\
\hline Father's age $20-30$ & $\begin{array}{c}34.563 * * * \\
(11.611)\end{array}$ & $\begin{array}{c}-0.019^{* *} \\
(0.008)\end{array}$ & $\begin{array}{c}0.043 \\
(0.045)\end{array}$ & $\begin{array}{c}-0.019 * * * \\
(0.007)\end{array}$ & $\begin{array}{c}0.830 * * * \\
(0.268)\end{array}$ \\
\hline Father's age $30-40$ & $\begin{array}{c}35.772 * * * \\
(11.567)\end{array}$ & $\begin{array}{c}-0.019 * * \\
(0.008)\end{array}$ & $\begin{array}{c}0.048 \\
(0.044)\end{array}$ & $\begin{array}{c}-0.019 * * * \\
(0.007)\end{array}$ & $\begin{array}{c}0.850 * * * \\
(0.269)\end{array}$ \\
\hline Father's age $40+$ & $\begin{array}{c}26.831^{* *} \\
(11.217)\end{array}$ & $\begin{array}{l}-0.012 \\
(0.008)\end{array}$ & $\begin{array}{l}-0.030 \\
(0.045)\end{array}$ & $\begin{array}{l}-0.011 \\
(0.007)\end{array}$ & $\begin{array}{c}0.770 * * * \\
(0.258)\end{array}$ \\
\hline Father high sch. grad. & $\begin{array}{c}22.922 * * * \\
(3.010)\end{array}$ & $\begin{array}{c}-0.005^{* * *} \\
(0.001)\end{array}$ & $\begin{array}{c}0.021^{* *} \\
(0.009)\end{array}$ & $\begin{array}{c}-0.004 * * * \\
(0.001)\end{array}$ & $\begin{array}{c}0.542 * * * \\
(0.072)\end{array}$ \\
\hline Father college grad. & $\begin{array}{c}28.771 * * * \\
(3.235)\end{array}$ & $\begin{array}{c}-0.010^{* * *} * \\
(0.001)\end{array}$ & $\begin{array}{c}0.069 * * * \\
(0.009)\end{array}$ & $\begin{array}{c}-0.008^{* * * *} \\
(0.001)\end{array}$ & $\begin{array}{c}0.601 * * * \\
(0.078)\end{array}$ \\
\hline $\mathrm{N}$ & $1,549,376$ & $1,549,376$ & $1,549,376$ & $1,549,376$ & $1,549,376$ \\
\hline
\end{tabular}

Notes: Outcome variables are baby's weight at birth in grams, an indicator for whether baby's birth weight is less than 2,500 grams, gestation weeks, an indicator for whether infant was born with gestational age less than 37 weeks, and the ratio of birth weight to gestation weeks in columns 1 to 5, respectively. Regressions include number of advisories, warnings, yellow dust events, average PM10, temperature and precipitation in each trimester instead of the whole pregnancy. Regressions also include city fixed effects, and time dummies for conception year and month. Standard errors clustered at the city level are presented in parentheses. $*, * *$ and $* * *$ indicate significance at $10 \%$, $5 \%$ and $1 \%$, respectively. 
Table 4: The Effect of Air Pollution on Birth Outcomes without Controlling for Pollution Alerts

\begin{tabular}{|c|c|c|c|c|c|}
\hline & $(1)$ & $(2)$ & (3) & (4) & $(5)$ \\
\hline & $\begin{array}{c}\text { Birth } \\
\text { Weight }\end{array}$ & $\begin{array}{c}\text { Low Birth } \\
\text { Weight }\end{array}$ & Gestation & $\begin{array}{c}\text { Premature } \\
\text { Birth }\end{array}$ & $\begin{array}{c}\text { Fetal } \\
\text { Growth }\end{array}$ \\
\hline PM10 & $\begin{array}{c}-0.232 * * \\
(0.101)\end{array}$ & $\begin{array}{c}0.0001^{* *} \\
(0.0000)\end{array}$ & $\begin{array}{l}-0.001 \\
(0.001)\end{array}$ & $\begin{array}{c}0.0001^{* * *} \\
(0.0000)\end{array}$ & $\begin{array}{c}-0.005^{*} \\
(0.003)\end{array}$ \\
\hline Temperature & $\begin{array}{c}-19.617 * * * \\
(1.595)\end{array}$ & $\begin{array}{c}0.005^{* * *} * \\
(0.001)\end{array}$ & $\begin{array}{c}-0.158 * * * \\
(0.009)\end{array}$ & $\begin{array}{l}0.002 * \\
(0.001)\end{array}$ & $\begin{array}{c}-0.181 * * * \\
(0.031)\end{array}$ \\
\hline Precipitation & $\begin{array}{c}-0.110^{* * *} \\
(0.019)\end{array}$ & $\begin{array}{c}0.0000 * * * \\
(0.0000)\end{array}$ & $\begin{array}{c}-0.001 * * * \\
(0.000)\end{array}$ & $\begin{array}{c}0.0000 * * * \\
(0.0000)\end{array}$ & $\begin{array}{c}-0.002 * * * \\
(0.000)\end{array}$ \\
\hline Girl & $\begin{array}{c}-97.641^{* * *} \\
(0.669)\end{array}$ & $\begin{array}{c}0.006^{* * * *} \\
(0.000)\end{array}$ & $\begin{array}{c}0.134 * * * \\
(0.003)\end{array}$ & $\begin{array}{c}-0.008^{* * * *} \\
(0.000)\end{array}$ & $\begin{array}{c}-2.785 * * * \\
(0.015)\end{array}$ \\
\hline Second baby & $\begin{array}{c}29.671^{* * * *} \\
(1.308)\end{array}$ & $\begin{array}{c}-0.010 * * * \\
(0.000)\end{array}$ & $\begin{array}{c}-0.405^{* * *} \\
(0.005)\end{array}$ & $\begin{array}{c}0.001 \\
(0.000)\end{array}$ & $\begin{array}{c}1.653 * * * \\
(0.029)\end{array}$ \\
\hline Third baby & $\begin{array}{c}61.713 * * * \\
(2.056)\end{array}$ & $\begin{array}{c}-0.010^{* * * *} \\
(0.001)\end{array}$ & $\begin{array}{c}-0.402 * * * \\
(0.006)\end{array}$ & $\begin{array}{c}0.006^{* * *} \\
(0.001)\end{array}$ & $\begin{array}{c}2.464 * * * \\
(0.050)\end{array}$ \\
\hline Married & $\begin{array}{c}31.471 * * * \\
(4.064)\end{array}$ & $\begin{array}{c}-0.012 * * * \\
(0.002)\end{array}$ & $\begin{array}{c}0.107 * * * \\
(0.012)\end{array}$ & $\begin{array}{c}-0.011 * * * \\
(0.002)\end{array}$ & $\begin{array}{c}0.606 * * * \\
(0.100)\end{array}$ \\
\hline Mother working & $\begin{array}{c}5.572 * * * \\
(0.925)\end{array}$ & $\begin{array}{l}-0.001 \\
(0.000)\end{array}$ & $\begin{array}{l}-0.002 \\
(0.003)\end{array}$ & $\begin{array}{c}0.0003 \\
(0.0003)\end{array}$ & $\begin{array}{c}0.145^{* * * *} \\
(0.022)\end{array}$ \\
\hline Mother's age 20-30 & $\begin{array}{c}66.830 * * * \\
(7.003)\end{array}$ & $\begin{array}{c}-0.006 * * \\
(0.003)\end{array}$ & $\begin{array}{c}0.066^{* * *} * \\
(0.023)\end{array}$ & $\begin{array}{c}-0.009 * * \\
(0.004)\end{array}$ & $\begin{array}{c}1.575 * * * \\
(0.167)\end{array}$ \\
\hline Mother's age $30-40$ & $\begin{array}{c}63.473 * * * \\
(7.048)\end{array}$ & $\begin{array}{c}0.001 \\
(0.003)\end{array}$ & $\begin{array}{l}-0.013 \\
(0.023)\end{array}$ & $\begin{array}{l}-0.002 \\
(0.004)\end{array}$ & $\begin{array}{c}1.634 * * * \\
(0.170)\end{array}$ \\
\hline Mother's age $40+$ & $\begin{array}{c}17.553^{* *} \\
(7.187)\end{array}$ & $\begin{array}{c}0.020 * * * \\
(0.003)\end{array}$ & $\begin{array}{c}-0.281 * * * \\
(0.026)\end{array}$ & $\begin{array}{c}0.022^{* * *} * \\
(0.004)\end{array}$ & $\begin{array}{c}0.979 * * * \\
(0.176)\end{array}$ \\
\hline Mother high sch. grad. & $\begin{array}{c}44.226^{* * * *} \\
(3.192)\end{array}$ & $\begin{array}{c}-0.011 * * * \\
(0.001)\end{array}$ & $\begin{array}{c}0.055^{* * *} * \\
(0.012)\end{array}$ & $\begin{array}{c}-0.006^{* * *} \\
(0.002)\end{array}$ & $\begin{array}{c}1.031 * * * \\
(0.073)\end{array}$ \\
\hline Mother college grad. & $\begin{array}{c}50.789 * * * \\
(3.400)\end{array}$ & $\begin{array}{c}-0.017 * * * \\
(0.002)\end{array}$ & $\begin{array}{c}0.116^{* * * *} \\
(0.012)\end{array}$ & $\begin{array}{c}-0.012 * * * \\
(0.002)\end{array}$ & $\begin{array}{c}1.082 * * * \\
(0.079)\end{array}$ \\
\hline Father working & $\begin{array}{c}8.956^{* * *} * \\
(1.503)\end{array}$ & $\begin{array}{c}-0.003 * * * \\
(0.001)\end{array}$ & $\begin{array}{c}-0.004 \\
(0.006)\end{array}$ & $\begin{array}{c}-0.004 * * * \\
(0.001)\end{array}$ & $\begin{array}{c}0.253 * * * \\
(0.035)\end{array}$ \\
\hline Father's age $20-30$ & $\begin{array}{c}33.031 * * * \\
(10.875)\end{array}$ & $\begin{array}{c}-0.016^{* *} \\
(0.007)\end{array}$ & $\begin{array}{c}0.025 \\
(0.043)\end{array}$ & $\begin{array}{c}-0.015 * * \\
(0.006)\end{array}$ & $\begin{array}{c}0.820 * * * \\
(0.250)\end{array}$ \\
\hline Father's age $30-40$ & $\begin{array}{c}34.821 * * * \\
(10.760)\end{array}$ & $\begin{array}{c}-0.016 * * \\
(0.007)\end{array}$ & $\begin{array}{c}0.031 \\
(0.042)\end{array}$ & $\begin{array}{c}-0.016^{* *} \\
(0.006)\end{array}$ & $\begin{array}{c}0.852 * * * \\
(0.249)\end{array}$ \\
\hline Father's age $40+$ & $\begin{array}{c}25.221 * * \\
(10.392)\end{array}$ & $\begin{array}{l}-0.009 \\
(0.007)\end{array}$ & $\begin{array}{l}-0.051 \\
(0.043)\end{array}$ & $\begin{array}{l}-0.007 \\
(0.007)\end{array}$ & $\begin{array}{c}0.761 * * * \\
(0.238)\end{array}$ \\
\hline Father high sch. grad. & $\begin{array}{c}21.935 * * * \\
(2.680)\end{array}$ & $\begin{array}{c}-0.006^{* * *} \\
(0.001)\end{array}$ & $\begin{array}{l}0.015^{*} \\
(0.009)\end{array}$ & $\begin{array}{c}-0.004 * * * \\
(0.001)\end{array}$ & $\begin{array}{c}0.529 * * * \\
(0.065)\end{array}$ \\
\hline Father college grad. & $\begin{array}{c}27.810^{* * *} \\
(2.945)\end{array}$ & $\begin{array}{c}-0.010^{* * *} \\
(0.001)\end{array}$ & $\begin{array}{c}0.063 * * * \\
(0.009)\end{array}$ & $\begin{array}{c}-0.008^{* * *} \\
(0.001)\end{array}$ & $\begin{array}{c}0.590 * * * \\
(0.072)\end{array}$ \\
\hline $\mathrm{N}$ & $1,676,096$ & $1,676,096$ & $1,676,096$ & $1,676,096$ & $1,676,096$ \\
\hline
\end{tabular}

Notes: Outcome variables are baby's weight at birth in grams, an indicator for whether baby's birth weight is less than 2,500 grams, gestation weeks, an indicator for whether infant was born with gestational age less than 37 weeks, and the ratio of birth weight to gestation weeks in columns 1 to 5 , respectively. Regressions include the whole set of covariates as in Table2 except Advisories, Warnings, and Yellow Dust Events. Standard errors clustered at the city level are presented in parentheses. *, ** and $* * *$ indicate significance at $10 \%, 5 \%$ and $1 \%$, respectively. 
Table 5: Effect of Yellow Dust Events and Air Quality Notifications on Soccer Attendance

\begin{tabular}{|c|c|c|}
\hline & $(1)$ & $(2)$ \\
\hline & Attendance & Log(Attendance) \\
\hline \multirow[t]{2}{*}{ PM10 } & 8.489 & 0.001 \\
\hline & $(7.277)$ & $(0.001)$ \\
\hline \multirow[t]{2}{*}{ Advisory } & 2346.761 & -0.041 \\
\hline & $(2423.710)$ & $(0.155)$ \\
\hline \multirow[t]{2}{*}{ Warning } & $-7051.620^{*}$ & $-0.564 *$ \\
\hline & $(3677.459)$ & $(0.277)$ \\
\hline \multirow[t]{2}{*}{ Yellow Dust Event } & $-3377.854 * *$ & $-0.219 * *$ \\
\hline & $(1237.069)$ & $(0.079)$ \\
\hline \multirow[t]{2}{*}{ Temperature $\left({ }^{\circ} \mathrm{C}\right)$} & $208.512 * * *$ & $0.020 * * *$ \\
\hline & $(36.196)$ & $(0.004)$ \\
\hline \multirow[t]{2}{*}{ Precipitation (mm.) } & $-61.354 * * *$ & $-0.007 * * *$ \\
\hline & $(8.527)$ & $(0.001)$ \\
\hline \multirow[t]{2}{*}{ Weekend } & -868.899 & 0.131 \\
\hline & (1781.747) & $(0.155)$ \\
\hline \multirow[t]{2}{*}{ Evening } & $-4470.460 * *$ & $-0.292 *$ \\
\hline & $(2008.817)$ & $(0.162)$ \\
\hline \multirow[t]{2}{*}{ Weekend $\times$ Evening } & $4978.367 * *$ & 0.301 \\
\hline & $(2027.002)$ & $(0.186)$ \\
\hline \multirow[t]{2}{*}{ Round in Tournament } & $-337.412 * * *$ & $-0.048 * * *$ \\
\hline & $(105.130)$ & $(0.011)$ \\
\hline \multirow[t]{2}{*}{ Home Team Goals For } & $203.218^{* *}$ & $0.025 * * *$ \\
\hline & $(78.056)$ & $(0.005)$ \\
\hline \multirow[t]{2}{*}{ Away Team Goals For } & 13.915 & 0.002 \\
\hline & $(43.662)$ & $(0.005)$ \\
\hline \multirow[t]{2}{*}{ Rank of Home Team } & $-218.622 * *$ & $-0.015^{*}$ \\
\hline & $(78.521)$ & $(0.007)$ \\
\hline \multirow[t]{2}{*}{ Rank of Away Team } & $-217.373^{* * *}$ & $-0.016^{* *}$ \\
\hline & $(72.318)$ & $(0.006)$ \\
\hline $\mathrm{N}$ & 1,061 & 1,061 \\
\hline
\end{tabular}

Notes: Outcome variable in column 1, Attendance, is the number of people who attended a soccer game in the Korean K-League between years 2004 and 2011. Mean Attendance is about 12,500. Outcome in column 2 is the natural logarithm of Attendance. Yellow Dust Event, Advisory and Warning are indicators for whether the corresponding notification is released on the game day. PM10 is the average of hourly measure in the game day. Temperature is the maximum temperature in Celsius in the day. Precipitation is measured in millimeters. Weekend denotes Saturday and Sunday games. Evening is equal to one if the whole game is played after sunset. Round in Tournament is the week number in the season. Goals For and Rank measures the number of goals scored by the corresponding team in the previous rounds in the tournament and the rank of the team as of the start of the game. Regressions also include stadium and team match-up fixed effects, year and month dummies. 
Table 6: Falsification Test: The Effect of Future Alerts and Air Quality on Birth Weight

\begin{tabular}{|c|c|c|c|c|}
\hline & $(1)$ & $(2)$ & $(3)$ & $(4)$ \\
\hline & $\begin{array}{l}\text { During } 30 \text { Days } \\
\text { following Birth }\end{array}$ & $\begin{array}{l}\text { During } 60 \text { Days } \\
\text { following Birth }\end{array}$ & $\begin{array}{l}\text { During } 90 \text { Days } \\
\text { following Birth }\end{array}$ & $\begin{array}{l}\text { During } 120 \text { Days } \\
\text { following Birth }\end{array}$ \\
\hline PM10 & $\begin{array}{c}-0.030 \\
(0.043)\end{array}$ & $\begin{array}{l}-0.067 \\
(0.056)\end{array}$ & $\begin{array}{c}-0.078 \\
(0.074)\end{array}$ & $\begin{array}{c}-0.113 \\
(0.082)\end{array}$ \\
\hline Advisories & $\begin{array}{l}-0.677 \\
(1.029)\end{array}$ & $\begin{array}{l}-0.171 \\
(0.731)\end{array}$ & $\begin{array}{l}-0.255 \\
(0.679)\end{array}$ & $\begin{array}{l}-0.743 \\
(0.596)\end{array}$ \\
\hline Warnings & $\begin{array}{c}1.217 \\
(1.888)\end{array}$ & $\begin{array}{c}0.118 \\
(1.457)\end{array}$ & $\begin{array}{c}0.239 \\
(1.335)\end{array}$ & $\begin{array}{l}-0.777 \\
(1.036)\end{array}$ \\
\hline Yellow dust events & $\begin{array}{c}0.371 \\
(0.397)\end{array}$ & $\begin{array}{c}0.396 \\
(0.297)\end{array}$ & $\begin{array}{l}0.470^{*} \\
(0.255)\end{array}$ & $\begin{array}{l}0.583^{* *} \\
(0.251)\end{array}$ \\
\hline Temperature & $\begin{array}{l}0.490 * \\
(0.252)\end{array}$ & $\begin{array}{c}0.070 \\
(0.240)\end{array}$ & $\begin{array}{c}0.590 * * \\
(0.251)\end{array}$ & $\begin{array}{c}0.350 \\
(0.293)\end{array}$ \\
\hline Precipitation & $\begin{array}{c}-0.011 * * * \\
(0.003)\end{array}$ & $\begin{array}{c}0.001 \\
(0.004)\end{array}$ & $\begin{array}{l}-0.003 \\
(0.004)\end{array}$ & $\begin{array}{l}-0.004 \\
(0.004)\end{array}$ \\
\hline Girl & $\begin{array}{c}-97.620 * * * \\
(0.748)\end{array}$ & $\begin{array}{c}-97.623 * * * \\
(0.755)\end{array}$ & $\begin{array}{c}-97.617 * * * \\
(0.743)\end{array}$ & $\begin{array}{c}-97.683 * * * \\
(0.725)\end{array}$ \\
\hline Second baby & $\begin{array}{c}29.991 * * * \\
(1.326)\end{array}$ & $\begin{array}{c}30.062 * * * \\
(1.338)\end{array}$ & $\begin{array}{c}29.985 * * * \\
(1.364)\end{array}$ & $\begin{array}{c}30.013 * * * \\
(1.365)\end{array}$ \\
\hline Third baby & $\begin{array}{c}59.912 * * * \\
(2.058)\end{array}$ & $\begin{array}{c}60.167 * * * \\
(2.067)\end{array}$ & $\begin{array}{c}60.216^{* * * *} \\
(2.074)\end{array}$ & $\begin{array}{c}60.058 * * * \\
(2.089)\end{array}$ \\
\hline Married & $\begin{array}{c}32.933 * * * \\
(3.979)\end{array}$ & $\begin{array}{c}32.651 * * * \\
(3.993)\end{array}$ & $\begin{array}{c}31.980 * * * \\
(4.072)\end{array}$ & $\begin{array}{c}32.619 * * * \\
(4.250)\end{array}$ \\
\hline Mother working & $\begin{array}{c}5.785 * * * \\
(0.958)\end{array}$ & $\begin{array}{c}5.921 * * * \\
(0.940)\end{array}$ & $\begin{array}{c}5.930 * * * \\
(0.936)\end{array}$ & $\begin{array}{c}5.718 * * * \\
(0.922)\end{array}$ \\
\hline Mother's age $20-30$ & $\begin{array}{c}70.595 * * * \\
(7.023)\end{array}$ & $\begin{array}{c}70.169 * * * \\
(7.047)\end{array}$ & $\begin{array}{c}69.749 * * * \\
(7.055)\end{array}$ & $\begin{array}{c}69.243 * * * \\
(7.096)\end{array}$ \\
\hline Mother's age $30-40$ & $\begin{array}{c}66.975 * * * \\
(7.082)\end{array}$ & $\begin{array}{c}66.499 * * * \\
(7.124)\end{array}$ & $\begin{array}{c}65.911 * * * \\
(7.134)\end{array}$ & $\begin{array}{c}65.358 * * * \\
(7.173)\end{array}$ \\
\hline Mother's age $40+$ & $\begin{array}{c}21.208 * * * \\
(7.385)\end{array}$ & $\begin{array}{c}20.996 * * * \\
(7.321)\end{array}$ & $\begin{array}{c}20.509 * * * \\
(7.208)\end{array}$ & $\begin{array}{c}19.847 * * * \\
(7.269)\end{array}$ \\
\hline Mother high sch. grad. & $\begin{array}{c}44.008 * * * \\
(3.342)\end{array}$ & $\begin{array}{c}44.002 * * * \\
(3.347)\end{array}$ & $\begin{array}{c}44.347 * * * \\
(3.352)\end{array}$ & $\begin{array}{c}44.684 * * * \\
(3.369)\end{array}$ \\
\hline Mother college grad. & $\begin{array}{c}50.406^{* * * *} \\
(3.544)\end{array}$ & $\begin{array}{c}50.293 * * * \\
(3.514)\end{array}$ & $\begin{array}{c}50.593 * * * \\
(3.534)\end{array}$ & $\begin{array}{c}51.092 * * * \\
(3.515)\end{array}$ \\
\hline Father working & $\begin{array}{c}8.356 * * * \\
(1.642)\end{array}$ & $\begin{array}{c}8.040 * * * \\
(1.641)\end{array}$ & $\begin{array}{c}8.200 * * * \\
(1.702)\end{array}$ & $\begin{array}{c}8.478 * * * \\
(1.738)\end{array}$ \\
\hline Father's age $20-30$ & $\begin{array}{c}32.471 * * * \\
(11.761)\end{array}$ & $\begin{array}{c}34.241 * * * \\
(11.566)\end{array}$ & $\begin{array}{c}36.141 * * * \\
(11.910)\end{array}$ & $\begin{array}{c}36.758 * * * \\
(12.234)\end{array}$ \\
\hline Father's age $30-40$ & $\begin{array}{c}34.017 * * * \\
(11.652)\end{array}$ & $\begin{array}{c}35.834 * * * \\
(11.473)\end{array}$ & $\begin{array}{c}37.795 * * * \\
(11.785)\end{array}$ & $\begin{array}{c}38.514 * * * \\
(12.124)\end{array}$ \\
\hline Father's age $40+$ & $\begin{array}{c}24.151^{* *} \\
(11.287)\end{array}$ & $\begin{array}{c}25.700^{* *} \\
(11.142)\end{array}$ & $\begin{array}{c}27.536^{* *} \\
(11.474)\end{array}$ & $\begin{array}{c}28.145^{* *} \\
(11.833)\end{array}$ \\
\hline Father high sch. grad. & $\begin{array}{c}22.267 * * * \\
(3.054)\end{array}$ & $\begin{array}{c}21.748^{* * *} \\
(3.116)\end{array}$ & $\begin{array}{c}22.192 * * * \\
(3.216)\end{array}$ & $\begin{array}{c}22.192 * * * \\
(3.185)\end{array}$ \\
\hline Father college grad. & $\begin{array}{c}28.361 * * * \\
(3.281) \\
\end{array}$ & $\begin{array}{c}27.915^{* * *} \\
(3.324) \\
\end{array}$ & $\begin{array}{c}28.364 * * * \\
(3.448) \\
\end{array}$ & $\begin{array}{c}28.353 * * * \\
(3.443) \\
\end{array}$ \\
\hline $\mathrm{N}$ & $1,516,650$ & $1,483,838$ & $1,450,696$ & $1,417,975$ \\
\hline
\end{tabular}

Notes: Outcome variable is baby's weight at birth in grams. Variables Advisories, Warnings, Yellow dust events, PM10, Temperature and Precipitation measure the corresponding variables 30, 60, 90 and 120 days following the baby's birth in columns 1 to 4, respectively. Full set of controls are included in regressions. Standard errors clustered at the city level are in parentheses. $*, * *$ and $* * *$ indicate significance at $10 \%, 5 \%$ and $1 \%$, respectively. 
Table 7: The Effect of Alerts and Air Pollution on Birth Weight in Subsamples

\begin{tabular}{lcccc}
\hline & $(1)$ & $(2)$ & $(3)$ & $(4)$ \\
& $\begin{array}{c}\text { Infants Born } \\
\text { in North West } \\
\text { Korea }\end{array}$ & $\begin{array}{c}\text { Infants Born } \\
\text { in Rest of } \\
\text { Korea }\end{array}$ & $\begin{array}{c}\text { Infants Born in } \\
\text { High PM10 Cities }\end{array}$ & $\begin{array}{c}\text { Infants Born in } \\
\text { Low PM10 Cities }\end{array}$ \\
\hline PM10 & $-0.982 * * *$ & $-1.216^{* * *}$ & $-1.079 * * *$ & $-0.743^{* *}$ \\
& $(0.209)$ & $(0.277)$ & $(0.195)$ & $(0.298)$ \\
Advisories & 2.560 & $5.154^{* * *}$ & 1.580 & $7.102^{* * *}$ \\
& $(1.738)$ & $(1.453)$ & $(1.284)$ & $(1.941)$ \\
Warnings & $8.640^{* * *}$ & $17.078^{* * *}$ & $14.920^{* * *}$ & $12.292^{* * *}$ \\
& $(2.210)$ & $(1.913)$ & $(2.014)$ & $(2.120)$ \\
Yellow dust events & $11.425 * * *$ & $7.738^{* * *}$ & $10.611^{* * *}$ & $7.537 * * *$ \\
& $(0.801)$ & $(0.457)$ & $(0.614)$ & $(0.475)$ \\
\hline $\mathrm{N}$ & 692,463 & 856,913 & 823,921 & 725,455 \\
\hline
\end{tabular}

\begin{tabular}{|c|c|c|c|c|c|c|}
\hline & (5) & (6) & (7) & (8) & (9) & (10) \\
\hline & Infants Born to & Infants Born to & First & Non-First & Infants Born & Infants Born to \\
\hline & High Educated & Low Educated & Born & Born & to Working & Non-Working \\
\hline & Mothers & Mothers & Infants & Infants & Mothers & Mothers \\
\hline \multirow[t]{2}{*}{ PM10 } & $-0.797 * * *$ & $-0.807 * * *$ & $-0.711 * * *$ & $-0.897 * * *$ & $-0.888 * * *$ & $-0.760 * * *$ \\
\hline & $(0.146)$ & $(0.198)$ & $(0.176)$ & $(0.164)$ & $(0.220)$ & $(0.148)$ \\
\hline \multirow[t]{2}{*}{ Advisories } & $4.000 * * *$ & $4.855 * * *$ & $4.109 * * *$ & $4.497 * * *$ & $3.282 * * *$ & $4.732 * * *$ \\
\hline & $(0.993)$ & $(1.277)$ & $(1.018)$ & $(1.116)$ & $(1.110)$ & $(1.078)$ \\
\hline \multirow[t]{2}{*}{ Warnings } & $13.568 * * *$ & $14.157 * * *$ & $14.404 * * *$ & $12.645 * * *$ & $13.780 * * *$ & $13.477 * * *$ \\
\hline & $(1.528)$ & $(2.344)$ & $(1.674)$ & $(1.744)$ & (1.664) & $(1.638)$ \\
\hline Yellow & $8.332 * * *$ & $9.077 * * *$ & $8.785 * * *$ & $8.359 * * *$ & $8.408 * * *$ & $8.652 * * *$ \\
\hline dust events & $(0.405)$ & $(0.526)$ & $(0.440)$ & $(0.420)$ & $(0.568)$ & $(0.416)$ \\
\hline $\mathrm{N}$ & $1,020,987$ & 528,389 & 835,108 & 714,268 & 445,974 & $1,103,402$ \\
\hline
\end{tabular}

Notes: Table 7 presents coefficients obtained from estimating the main specification over subsamples described at the top of each column. Outcome variable is baby's weight at birth in grams. Full set of control variables are included in all regressions. Standard errors clustered at the city level are presented in parentheses. *, ** and *** indicate significance at $10 \%, 5 \%$ and 1\%, respectively. Subsamples: Infants born in/to (1) Regions in North and North West Korea Seoul, Gangwon and Chungnam vs. (2) Rest of Korea; (3) Regions with average PM10 level greater than the median vs. (4) Regions with average PM10 level less than the median; (5) Mothers with at least a college degree vs. (6) Mothers with less than college degree; (7) Mothers of their first children vs. (8) Mother who have given birth before; (9) Working mothers vs. (10) Mother who are not working. 


\section{Table 8}

\section{Characteristics of Families Whose Infants are Born in Polluted Areas}

\begin{tabular}{|c|c|c|}
\hline & $(1)$ & $(2)$ \\
\hline & $\begin{array}{l}\text { Born in High } \\
\text { PM10 city }\end{array}$ & $\begin{array}{l}\text { Born in High } \\
\text { PM10 city }\end{array}$ \\
\hline White Collar Family & & $\begin{array}{c}0.050 * * * \\
(0.015)\end{array}$ \\
\hline Second baby & $\begin{array}{c}-0.044 * * * \\
(0.010)\end{array}$ & $\begin{array}{c}-0.044 * * * \\
(0.010)\end{array}$ \\
\hline Third baby & $\begin{array}{c}-0.102 * * * \\
(0.020)\end{array}$ & $\begin{array}{c}-0.101 * * * \\
(0.020)\end{array}$ \\
\hline Married & $\begin{array}{l}0.033^{*} \\
(0.019)\end{array}$ & $\begin{array}{l}0.033^{*} \\
(0.020)\end{array}$ \\
\hline Mother working & $\begin{array}{c}0.035^{* * * *} \\
(0.012)\end{array}$ & \\
\hline Mother's age 20-30 & $\begin{array}{c}0.059 * * * \\
(0.012)\end{array}$ & $\begin{array}{c}0.061 * * * \\
(0.012)\end{array}$ \\
\hline Mother's age $30-40$ & $\begin{array}{c}0.109 * * * \\
(0.018)\end{array}$ & $\begin{array}{c}0.111 * * * \\
(0.019)\end{array}$ \\
\hline Mother's age $40+$ & $\begin{array}{c}0.127 * * * \\
(0.021)\end{array}$ & $\begin{array}{c}0.130 * * * \\
(0.021)\end{array}$ \\
\hline Mother high sch. grad. & $\begin{array}{c}0.037 * * * \\
(0.009)\end{array}$ & $\begin{array}{c}0.038 * * * \\
(0.010)\end{array}$ \\
\hline Mother college grad. & $\begin{array}{c}0.002 \\
(0.018)\end{array}$ & $\begin{array}{c}0.002 \\
(0.018)\end{array}$ \\
\hline Father working & $\begin{array}{c}0.017 \\
(0.013)\end{array}$ & \\
\hline Father's age $20-30$ & $\begin{array}{l}-0.015 \\
(0.016)\end{array}$ & $\begin{array}{c}-0.008 \\
(0.016)\end{array}$ \\
\hline Father's age $30-40$ & $\begin{array}{l}-0.003 \\
(0.018)\end{array}$ & $\begin{array}{c}0.004 \\
(0.017)\end{array}$ \\
\hline Father's age $40+$ & $\begin{array}{c}0.000 \\
(0.021)\end{array}$ & $\begin{array}{c}0.008 \\
(0.020)\end{array}$ \\
\hline Father high sch. grad. & $\begin{array}{c}0.000 \\
(0.010)\end{array}$ & $\begin{array}{c}0.002 \\
(0.010)\end{array}$ \\
\hline Father college grad. & $\begin{array}{l}-0.012 \\
(0.019)\end{array}$ & $\begin{array}{l}-0.013 \\
(0.018) \\
\end{array}$ \\
\hline $\mathrm{N}$ & $1,549,376$ & $1,549,376$ \\
\hline
\end{tabular}

The outcome variable is an indicator that takes the value of one if the baby is born in a city where the average PM10 level is greater than the median. Regressions also include month and year of conception dummies. High Family Income is equal to one if both parents of the infant have white collar jobs such as managers, engineers and office workers, and it is equal to zero if at least one parent has a blue collar job such as laborer or technician or an agricultural job. Standard errors clustered at the city level are presented in parentheses. * ** and *** indicate significance at $10 \%, 5 \%$ and $1 \%$, respectively. 
Table 9: The Effect of Alerts and Air Pollution on Birth Outcomes Controlling for Housing Price Index and a Proxy for the Productive Efficiency of the Family

Panel A

\begin{tabular}{lccccc}
\hline & $(1)$ & $(2)$ & $(3)$ & $(4)$ & $(5)$ \\
\hline & Birth Weight & Low Birth Weight & $\begin{array}{c}\text { Gestation } \\
\text { Premature } \\
\text { Birth }\end{array}$ & $\begin{array}{c}\text { Fetal } \\
\text { Growth }\end{array}$ \\
\hline PM10 & $-1.241^{* * *}$ & $0.0005^{* * *}$ & $-0.008^{* * *}$ & $0.001^{* * *}$ & $-0.016^{* * *}$ \\
& $(0.202)$ & $(0.000)$ & $(0.002)$ & $(0.000)$ & $(0.003)$ \\
Housing Price Index -9$)$ & $0.333^{* * *}$ & $-0.000^{* * *}$ & $0.003^{* * *}$ & $-0.0005^{* * *}$ & $0.004^{* *}$ \\
& $(0.113)$ & $(0.000)$ & $(0.001)$ & $(0.000)$ & $(0.002)$ \\
White Collar Family & $1.880^{*}$ & -0.001 & 0.003 & 0.0001 & $0.042^{*}$ \\
& $(0.998)$ & $(0.000)$ & $(0.003)$ & $(0.0004)$ & $(0.023)$ \\
Advisories & $5.399^{* * *}$ & $-0.003^{* * *}$ & $0.046^{* * *}$ & $-0.006^{* * *}$ & $0.054^{* * *}$ \\
& $(1.090)$ & $(0.000)$ & $(0.006)$ & $(0.001)$ & $(0.019)$ \\
Warnings & $15.094^{* * *}$ & $-0.005^{* * *}$ & $0.094^{* * *}$ & $-0.007 * * *$ & $0.209^{* * *}$ \\
& $(1.418)$ & $(0.001)$ & $(0.008)$ & $(0.001)$ & $(0.028)$ \\
Yellow dust events & $8.662^{* * *}$ & $-0.003^{* * *}$ & $0.058^{* * *}$ & $-0.006^{* * *}$ & $0.114^{* * *}$ \\
& $(0.427)$ & $(0.000)$ & $(0.002)$ & $(0.000)$ & $(0.007)$ \\
\hline $\mathrm{N}$ & $1,376,282$ & $1,376,282$ & $1,376,282$ & $1,376,282$ & $1,376,282$ \\
\hline
\end{tabular}

Panel B

\begin{tabular}{lccccc}
\hline & $(1)$ & $(2)$ & $(3)$ & $(4)$ & $(5)$ \\
\hline PM10 & Birth Weight & Low Birth Weight & Gestation & Premature Birth & Fetal Growth \\
& $-1.265^{* * *}$ & $0.0005^{* * *}$ & $-0.009^{* * *}$ & $0.001^{* * *}$ & $-0.016^{* * *}$ \\
Advisories & $(0.204)$ & $(0.000)$ & $(0.002)$ & $(0.000)$ & $(0.003)$ \\
& $4.757^{* * *}$ & $-0.002^{* * *}$ & $0.041^{* * *}$ & $-0.005^{* * *}$ & $0.046^{* *}$ \\
Warnings & $(1.103)$ & $(0.000)$ & $(0.006)$ & $(0.001)$ & $(0.019)$ \\
& $16.213^{* * *}$ & $-0.006^{* * *}$ & $0.103^{* * *}$ & $-0.009^{* * *}$ & $0.222^{* * *}$ \\
Yellow dust events & $(1.501)$ & $(0.001)$ & $(0.008)$ & $(0.001)$ & $(0.029)$ \\
& $8.585^{* * *}$ & $-0.003^{* * *}$ & $0.058^{* * *}$ & $-0.006^{* * *}$ & $0.113^{* * *}$ \\
$\mathrm{~N}$ & $(0.413)$ & $(0.000)$ & $(0.002)$ & $(0.000)$ & $(0.007)$ \\
\hline
\end{tabular}

Notes: The Housing Price Index pertains to the city of infant's birth, 9 months before the infant's birth date. White Collar Family is equal to one if both parents of the infant have white collar jobs such as managers, engineers and office workers, and it is equal to zero if at least one parent has a blue collar job such as laborer or technician or an agricultural job. Regressions in Panel A include Housing Price Index, and White Collar Family in addition to the control variables as in Table 2. Regressions in Panel B include all control variables except for Housing price Index and White Collar Family. The coefficients of the full set of control variables are listed in Appendix Table 2.

Standard errors clustered at the city level are presented in parentheses. * $* *$ and $* * *$ indicate significance at $10 \%$, $5 \%$ and $1 \%$, respectively. 
Figure 1

Average Hourly PM10 Concentrations in Our Sample between Years 2003 and 2006
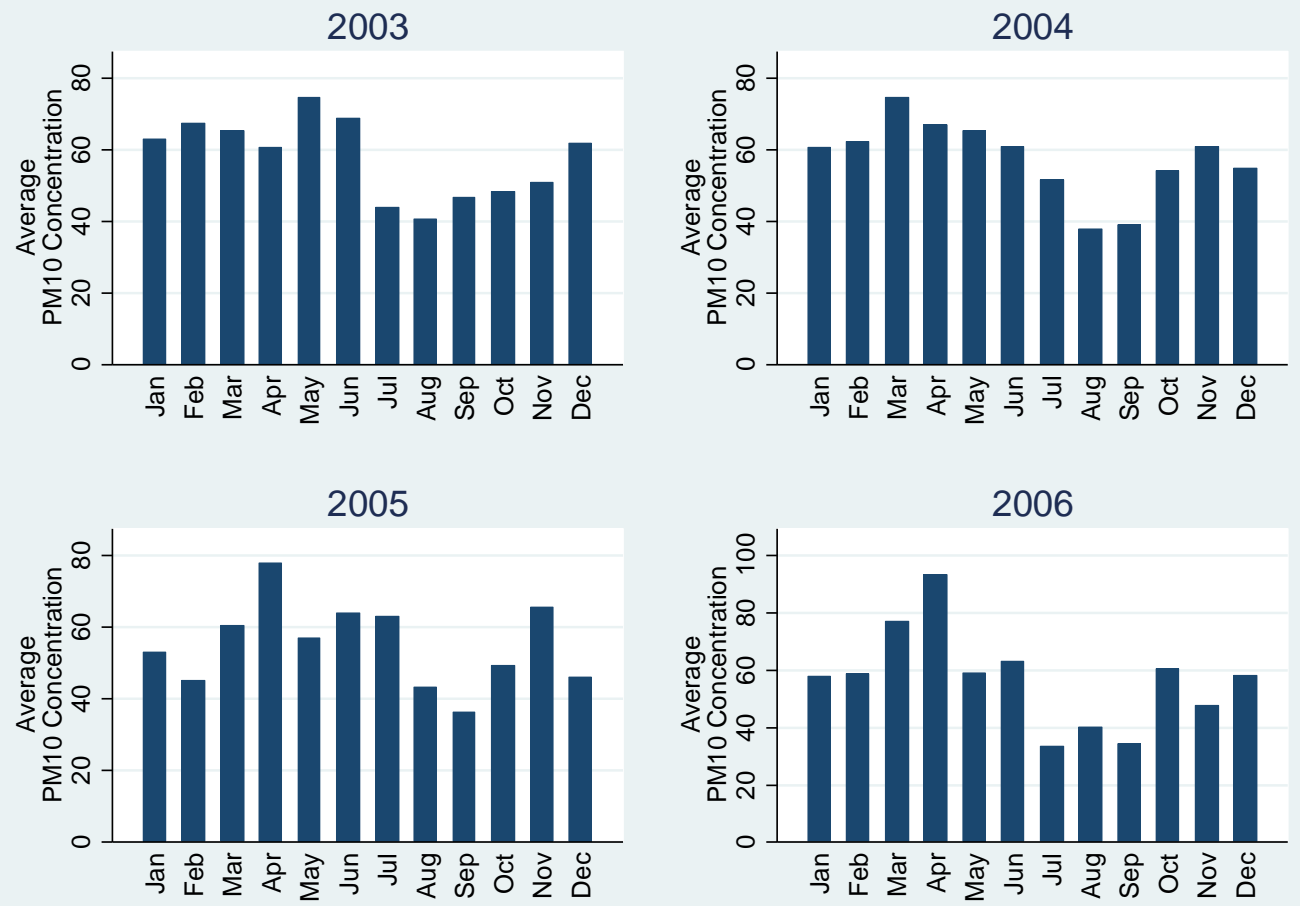
Figure 2

Average Daily PM10 Concentrations in each Region across Korea between Years 2003 and 2011
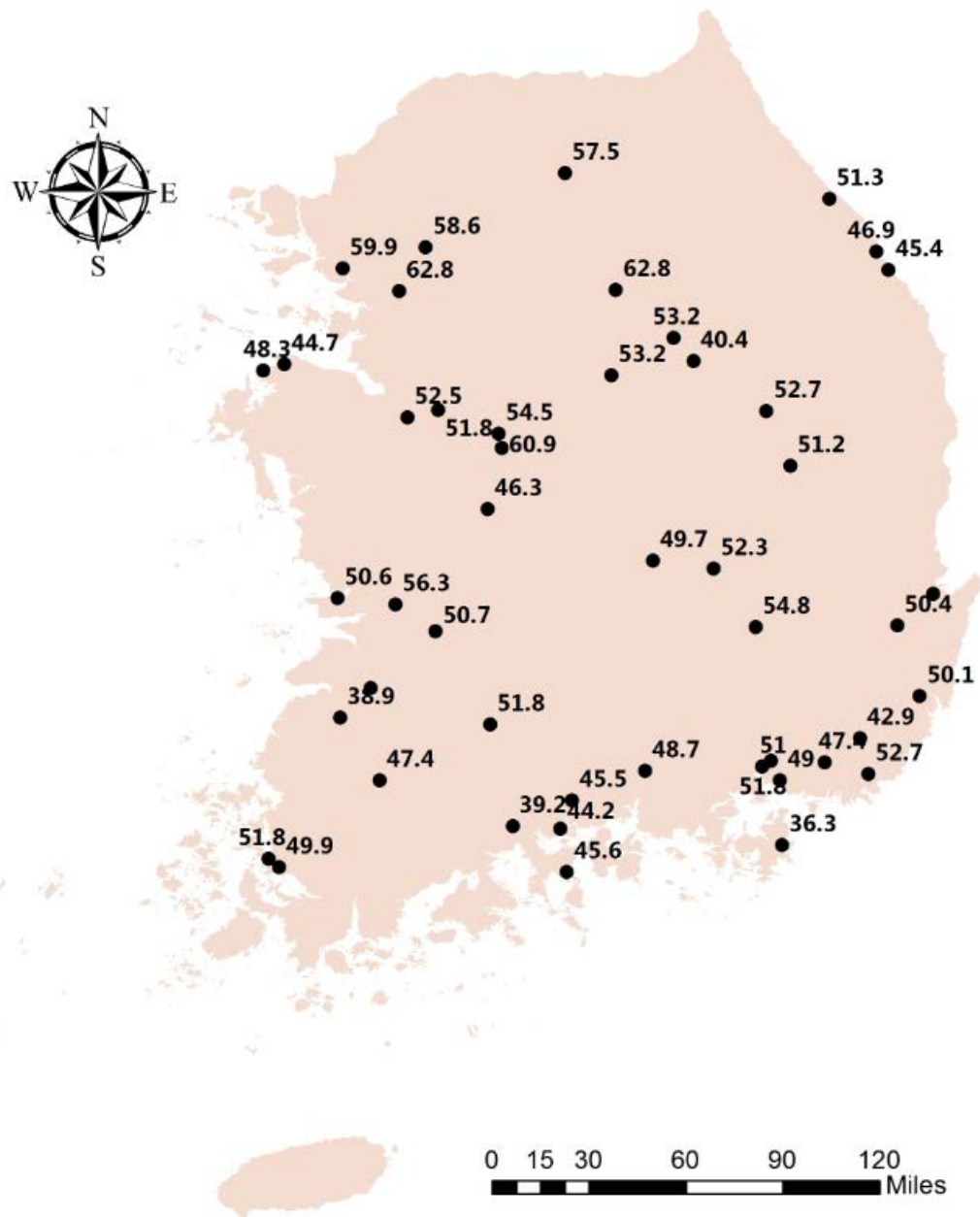


\section{Figure 3}

\section{Conceptions by Month}

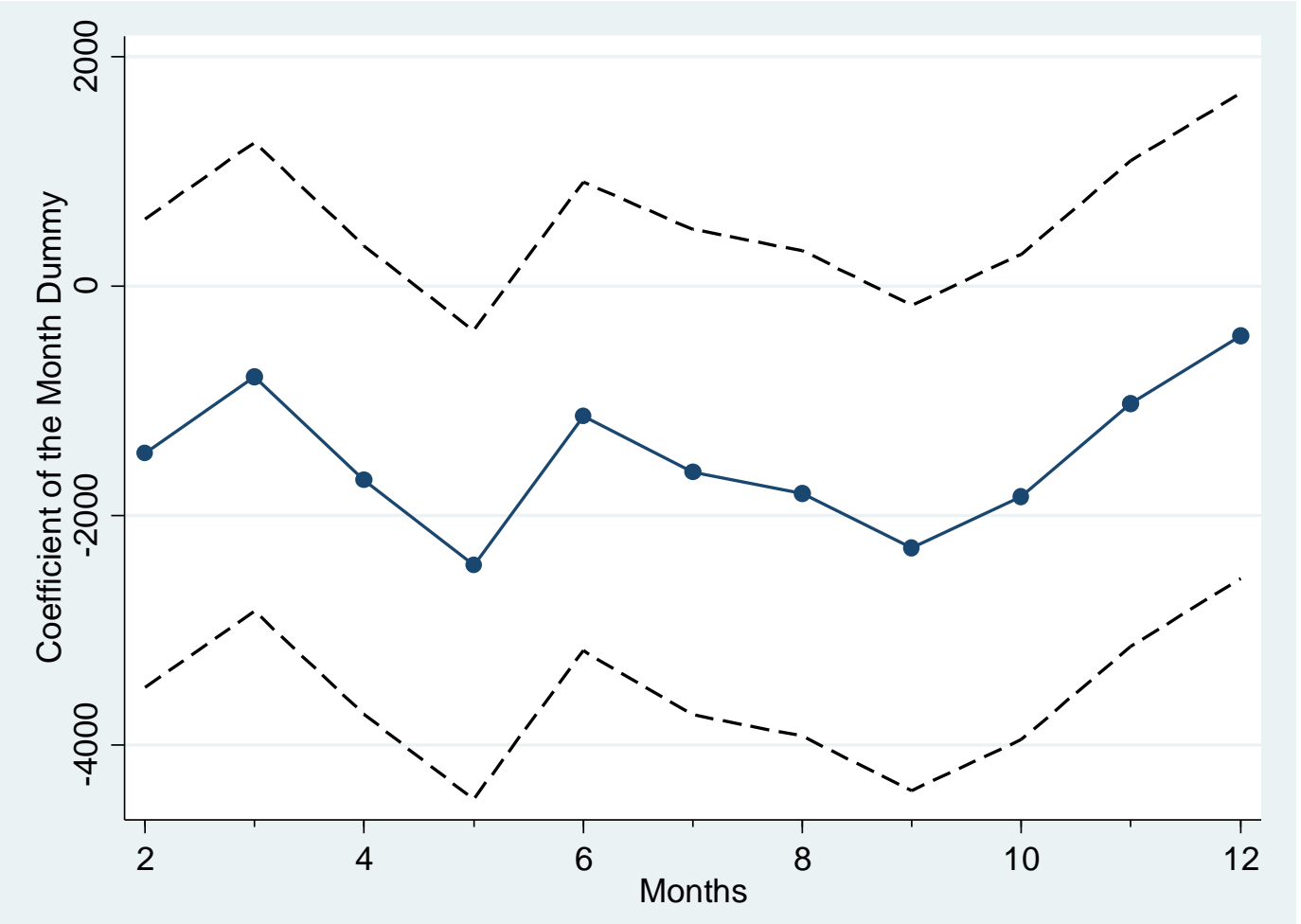

The figure presents the estimates obtained from a regression with outcome variable Number of Conceptions in a month. The unit of observation is a month-year. The independent variables are month and year dummies. January is the omitted category. The solid connected line is the coefficient estimates of the month dummies. The dashed lines represent 2 standard deviation confidence intervals. 
Appendix Table 1: Characteristics Infants and Parents in and out of Sample

\begin{tabular}{lrrrr}
\hline & \multicolumn{2}{c}{ In the Sample } & \multicolumn{2}{c}{ Out of Sample } \\
\hline Variable & Mean & \multicolumn{1}{c}{ Std. } & Mean & Std. Dev. \\
\hline Birth weight & 3257 & 430 & 3262 & 439 \\
Low birth weight & 0.030 & 0.180 & 0.030 & 0.180 \\
Gestation & 38.94 & 1.48 & 38.85 & 2.55 \\
Premature & 0.040 & 0.200 & 0.040 & 0.200 \\
Fetal growth & 83.54 & 10.20 & 83.63 & 10.43 \\
Singleton & 1.000 & 0.000 & 1.000 & 0.000 \\
Girl & 0.480 & 0.500 & 0.480 & 0.500 \\
Second baby & 0.380 & 0.480 & 0.390 & 0.490 \\
Third baby & 0.080 & 0.280 & 0.100 & 0.300 \\
Married & 0.990 & 0.100 & 0.980 & 0.140 \\
Mother working & 0.290 & 0.450 & 0.230 & 0.420 \\
Mother's age 20-30 & 0.410 & 0.490 & 0.470 & 0.500 \\
Mother's age 30-40 & 0.570 & 0.490 & 0.510 & 0.500 \\
Mother's age 40+ & 0.020 & 0.120 & 0.020 & 0.120 \\
Mother high school grad. & 0.320 & 0.470 & 0.410 & 0.490 \\
Mother college grad. & 0.660 & 0.470 & 0.560 & 0.500 \\
Father working & 0.950 & 0.210 & 0.960 & 0.200 \\
Father's age 20-30 & 0.180 & 0.380 & 0.220 & 0.420 \\
Father's age 30-40 & 0.750 & 0.430 & 0.710 & 0.460 \\
Father's age 40+ & 0.070 & 0.250 & 0.070 & 0.250 \\
Father high school grad. & 0.290 & 0.450 & 0.360 & 0.480 \\
Father college grad. & 0.690 & 0.460 & 0.610 & 0.490 \\
\hline Number of observations & $5 n+10$ & & \\
\hline
\end{tabular}

Number of observations in the sample of births that are not included in the regressions is about 2.5 million. 


\section{Appendix Table 2: The Coefficients of the Full Set of Control Variables in Table 9}

\begin{tabular}{|c|c|c|c|c|c|}
\hline & (1) & (2) & (3) & (4) & (5) \\
\hline & Birth Weight & Low Birth Weight & Gestation & Premature Birth & Fetal Growth \\
\hline \multirow[t]{2}{*}{ PM10 } & $-1.241 * * *$ & $0.000 * * *$ & $-0.008 * * *$ & $0.001 * * *$ & $-0.016^{* * *}$ \\
\hline & $(0.202)$ & $(0.000)$ & $(0.002)$ & $(0.000)$ & $(0.003)$ \\
\hline \multirow[t]{2}{*}{ Housing Price Index $x_{t-9}$} & $0.333 * * *$ & $-0.000 * * *$ & $0.003 * * *$ & $-0.000 * * *$ & $0.004 * *$ \\
\hline & $(0.113)$ & $(0.000)$ & $(0.001)$ & $(0.000)$ & $(0.002)$ \\
\hline \multirow[t]{2}{*}{ White Collar Family } & $1.880 *$ & -0.001 & 0.003 & 0.000 & $0.042 *$ \\
\hline & $(0.998)$ & $(0.000)$ & $(0.003)$ & $(0.000)$ & $(0.023)$ \\
\hline \multirow[t]{2}{*}{ Advisories } & $5.399 * * *$ & $-0.003 * * *$ & $0.046 * * *$ & $-0.006 * * *$ & $0.054 * * *$ \\
\hline & (1.090) & $(0.000)$ & $(0.006)$ & $(0.001)$ & $(0.019)$ \\
\hline \multirow[t]{2}{*}{ Warnings } & $15.094 * * *$ & $-0.005 * * *$ & $0.094 * * *$ & $-0.007 * * *$ & $0.209 * * *$ \\
\hline & $(1.418)$ & $(0.001)$ & $(0.008)$ & $(0.001)$ & $(0.028)$ \\
\hline \multirow[t]{2}{*}{ Yellow dust events } & $8.662 * * *$ & $-0.003 * * *$ & $0.058 * * *$ & $-0.006 * * *$ & $0.114 * * *$ \\
\hline & $(0.427)$ & $(0.000)$ & $(0.002)$ & $(0.000)$ & $(0.007)$ \\
\hline \multirow[t]{2}{*}{ Temperature } & $-18.923 * * *$ & $0.005 * * *$ & $-0.141 * * *$ & 0.002 & $-0.203 * * *$ \\
\hline & $(1.748)$ & $(0.001)$ & $(0.009)$ & $(0.001)$ & $(0.035)$ \\
\hline \multirow[t]{2}{*}{ Precipitation } & $-0.167 * * *$ & $0.000 * * *$ & $-0.001 * * *$ & $0.000 * * *$ & $-0.003 * * *$ \\
\hline & $(0.031)$ & $(0.000)$ & $(0.000)$ & $(0.000)$ & $(0.001)$ \\
\hline \multirow[t]{2}{*}{ Girl } & $-98.022 * * *$ & $0.006^{* * *}$ & $0.134 * * *$ & $-0.008 * * *$ & $-2.795 * * *$ \\
\hline & $(0.826)$ & $(0.000)$ & $(0.003)$ & $(0.000)$ & $(0.018)$ \\
\hline \multirow[t]{2}{*}{ Second baby } & $30.348 * * *$ & $-0.011 * * *$ & $-0.407 * * *$ & 0.000 & $1.677 * * *$ \\
\hline & $(1.382)$ & $(0.000)$ & $(0.005)$ & $(0.000)$ & $(0.031)$ \\
\hline \multirow[t]{2}{*}{ Third baby } & $59.992 * * *$ & $-0.010 * * *$ & $-0.417 * * *$ & $0.007 * * *$ & $2.452 * * *$ \\
\hline & $(1.983)$ & $(0.001)$ & $(0.006)$ & $(0.001)$ & $(0.049)$ \\
\hline \multirow[t]{2}{*}{ Married } & $31.388 * * *$ & $-0.011 * * *$ & $0.111^{* * *}$ & $-0.012 * * *$ & $0.591 * * *$ \\
\hline & $(4.131)$ & $(0.002)$ & $(0.014)$ & $(0.002)$ & $(0.100)$ \\
\hline \multirow[t]{2}{*}{ Mother's age 20-30 } & $67.169 * * *$ & $-0.007 * *$ & $0.043 *$ & $-0.008 *$ & $1.626^{* * *}$ \\
\hline & $(6.970)$ & $(0.003)$ & $(0.025)$ & $(0.004)$ & $(0.172)$ \\
\hline \multirow[t]{2}{*}{ Mother's age $30-40$} & $65.313 * * *$ & 0.000 & -0.029 & -0.002 & $1.710 * * *$ \\
\hline & $(6.911)$ & $(0.003)$ & $(0.025)$ & $(0.004)$ & $(0.171)$ \\
\hline \multirow[t]{2}{*}{ Mother's age $40+$} & $22.993 * * *$ & $0.018 * * *$ & $-0.290 * * *$ & $0.021 * * *$ & $1.135 * * *$ \\
\hline & $(7.428)$ & $(0.004)$ & $(0.030)$ & $(0.005)$ & $(0.183)$ \\
\hline \multirow[t]{2}{*}{ Mother high sch. grad. } & $44.026^{* * *}$ & $-0.010 * * *$ & $0.050 * * *$ & $-0.005^{* * *}$ & $1.034 * * *$ \\
\hline & $(3.726)$ & $(0.002)$ & $(0.012)$ & $(0.002)$ & $(0.086)$ \\
\hline \multirow[t]{2}{*}{ Mother college grad. } & $51.570 * * *$ & $-0.016^{* * *}$ & $0.115^{* * *}$ & $-0.011 * * *$ & $1.100 * * *$ \\
\hline & $(3.848)$ & $(0.002)$ & $(0.013)$ & $(0.002)$ & $(0.088)$ \\
\hline \multirow[t]{2}{*}{ Father's age $20-30$} & $30.052 * *$ & $-0.018 * *$ & 0.028 & $-0.021 * * *$ & $0.740 * * *$ \\
\hline & $(11.517)$ & $(0.007)$ & $(0.046)$ & $(0.007)$ & $(0.269)$ \\
\hline \multirow[t]{2}{*}{ Father's age $30-40$} & $31.742 * * *$ & $-0.018 * *$ & 0.036 & $-0.022 * * *$ & $0.766^{* * *}$ \\
\hline & $(11.337)$ & $(0.007)$ & $(0.046)$ & $(0.007)$ & $(0.267)$ \\
\hline \multirow[t]{2}{*}{ Father's age $40+$} & $22.727 * *$ & -0.011 & -0.042 & $-0.013 *$ & $0.682 * *$ \\
\hline & $(11.062)$ & $(0.007)$ & $(0.046)$ & $(0.007)$ & $(0.258)$ \\
\hline \multirow[t]{2}{*}{ Father high sch. grad. } & $22.008 * * *$ & $-0.005 * * *$ & $0.015^{*}$ & $-0.003 *$ & $0.533 * * *$ \\
\hline & $(3.146)$ & $(0.001)$ & $(0.009)$ & $(0.001)$ & $(0.077)$ \\
\hline \multirow[t]{2}{*}{ Father college grad. } & $28.682 * * *$ & $-0.009 * * *$ & $0.067 * * *$ & $-0.008 * * *$ & $0.606^{* * *}$ \\
\hline & $(3.357)$ & $(0.001)$ & $(0.010)$ & $(0.001)$ & $(0.083)$ \\
\hline $\mathrm{N}$ & $1,376,282$ & $1,376,282$ & $1,376,282$ & $1,376,282$ & $1,376,282$ \\
\hline
\end{tabular}




\section{References}

Agarwal, N., C. Banternghansa, and L. Bui. 2010. "Toxic Exposure in America: Estimating Fetal and Infant Health Outcomes from 14 Years of TRI Reporting." Journal of Health Economics 29(4), pp. 557-574.

Almond, D. 2006. "Is the 1918 Influenza Pandemic Over? Long Term Effects of In Utero Influenza Exposure in the Post-1940 U.S. Population.” Journal of Political Economy 114(4), pp. 672-712.

Almond, D., K. Chay, and D. Lee. 2005. "The Costs of Low Birth Weight.” Quarterly Journal of Economics 120(3), pp. 1031-1083.

Almond, D., and J. Currie, 2011. "Human Capital Development before Age Five" Handbook of Labor Economics, Ed.: Orley Ashenfelter and David Card, pp. 1315-1486.

Almond, D., H. Hoynes, and D. Schanzenbach. 2011. "Inside the War on Poverty: The Impact of Food Stamps on Birth Outcomes." Review of Economics and Statistics 93(2), pp. 387-403.

Altindag, D., C. Cannonier., and N. Mocan. 2011. "The Impact of Education on Health Knowledge." Economics of Education Review 30(5), pp. 792-812.

Black, S., P. Devereux, and K. Salvanes. 2007. "From the Cradle to the Labor Market? The Effect of Birth Weight on Adult Outcomes.” Quarterly Journal of Economics 122(1), pp. 409-39.

Black, S., A. Bütikofer, P. Devereux, and K. Salvanes. 2013. "This Is Only a Test? Long-Run and Intergenerational Impacts of Prenatal Exposure to Radioactive Downfall." NBER Working Paper No. 18987.

Chay, K., and M. Greenstone. 2005. "Does Air Quality Matter? Evidence from the Housing Market.” Journal of Political Economy 113(2), pp. 376-424.

Chay, K. and Greenstone, M. 2003. "The Impact of Air Pollution on Infant Mortality: Evidence from Geographic Variation in Pollution Shocks Induced by a Recession." Quarterly Journal of Economics 118(3), pp. 1121-1167.

Chou, S., J. Liu, M. Grossman, T. Joyce. 2010. "Parental Education and Child Health: Evidence from a Natural Experiment in Taiwan.” American Economic Journal: Applied Economics 2(1), pp. 33-61.

Chun, Y., K. Boo, J. Kim, S. Park, and M. Lee. 2001. "Synopsis, Transport, and Physical Characteristics of Asian Dust In Korea," Journal of Geophysical Research 106, pp. 1846118469.

Coneus, K., and C. Spiess. 2012. "Pollution Exposure and Child Health: Evidence for Infants and Toddlers in Germany," Journal of Health Economics 31(1), pp. 180-196.

Currie, J., L. Davis, M. Greenstone, and R. Walker. 2015. "Environmental Health Risks and Housing Values: Evidence from 1,600 Toxic Plant Openings and Closings.” American Economic Review 105(2), pp. 678-709.

Currie, J., and R. Walker. 2012. "Traffic Congestion and Infant Health: Evidence from E-ZPass." American Economic Journal: Applied Economics 3, pp. 65-90. 
Currie, J. 2011. "Inequality At Birth: Some Causes and Consequences.” American Economic Review 101(3), pp. 1-22.

Currie, J., M. Neidell, and J. Schmieder. 2009. "Air Pollution and Infant Health: Lessons from New Jersey.” Journal of Health Economics 28, pp. 688-703.

Currie, J., and M. Neidell. 2005. "Air Pollution and Infant Health: What Can We Learn from California's Recent Experience?” Quarterly Journal of Economics 120(3), pp. 1003-1030.

Currie, K. J. Zivin, J. Mullins, and M. Neidell. 2014. "What Do We Know About Short- and Long-Term Effects of Early-Life Exposure to Pollution?" Annual Review of Resource Economics 6(1), pp. 217-247.

Dehejia, R., and A. Lleras-Muney. 2004. “Booms, Busts and Babies Health.” Quarterly Journal of Economics 119(3), pp. 1091-1130.

Greenstone, M., and R. Hanna. 2014. "Environmental Regulations, Air and Water Pollution, and Infant Mortality in India.” American Economic Review 104(10), pp. 3038-3072.

Grossman, M. 1972. "On the Concept of Health Capital and the Demand for Health." The Journal of Political Economy 80(2), pp. 223-255.

Grossman, M. 2008. “The Relationship between Health and Schooling." Eastern Economic Journal 34, pp. 281-292.

Grossman, M., and T. Joyce. 1990. "Unobservables, Pregnancy Resolutions, and Birth Weight Production Functions in New York City." Journal of Political Economy 98(5), pp. 983-1007.

Janke, K. 2014. “Air Pollution, Avoidance Behaviour and Children's Respiratory Health: Evidence from England.” Journal of Health Economics 38, pp. 23-42.

Jayachandran, S. 2009. “Air Quality and Early-Life Mortality: Evidence from Indonesia's Wildfires." Journal of Human Resources 44(4), pp. 916-954.

Jia, R., and H. Ku. 2015. "Is China's Pollution the Culprit for the Choking of South Korea? Evidence from the Asian Dust." Working paper, available at $<$ https://docs.google.com/viewer?a=v\&pid=sites\&srcid=ZGVmYXVsdGRvbWFpbnxoeWV qa3V8Z3g6NTJhY2JiMjk4MGZ1MDdlMg>

Kenkel, D. 1991. "Health Behavior, Health Knowledge, and Schooling." Journal of Political Economy 99(2), pp. 287-305.

Knittel, C., D. Miller, and N. Sanders. 2011. "Caution, Drivers! Children Present: Traffic, Pollution, and Infant Health." NBER Working Paper No. 17222.

Lee, J., J. Son, and Y. Cho, 2007. "A Comparison of Mortality Related to Urban Air Particles between Periods with Asian Dust Days and without Asian Dust Days in Seoul, Korea, 20002004." Environmental Research 105(3), pp. 409-413.

Lien, D., and W. Evans. 2005. "Estimating the Impact of Large Cigarette Tax Hikes: The Case of Maternal Smoking and Infant Birth Weight." Journal of Human Resources 40(2), pp. 373392.

Luechinger, S. 2014. “Air Pollution and Infant Mortality: A Natural Experiment from Power Plant Desulfurization.” Journal of Health Economics 37, pp. 219-231. 
McCrary, J., and H. Royer. 2011. "The Effect of Female Education on Fertility and Infant Health: Evidence from School Entry Policies Using Exact Date of Birth.” American Economic Review 101(1), pp. 158-95.

Mocan, N., C. Raschke, and B. Unel. 2013. "The Impact of Mothers' Earnings on Health Inputs and Infant Health." Forthcoming in Economics and Human Biology.

Moretti, E. and M. Neidell, 2011. "Pollution, Health, and Avoidance Behavior: Evidence from the Ports of Los Angeles." Journal of Human Resources 46(1), pp. 154-175.

Neidell, M. 2004. "Air Pollution, Health, and Socio-Economic Status: The Effect of Outdoor Air Quality on Childhood Asthma." Journal of Health Economics 23(6), pp. 1209-1236.

Neidell, M. 2009. “Information, Avoidance Behavior, and Health: The Effect of ozone On Asthma Hospitalizations.” Journal of Human Resources 44(2), pp. 450-478.

Park, J., Y. Lim, S. Kyung, C. An, S. Lee, S. Jeong, and Y. Ju. 2005. "Effects of Ambient Particulate Matter on Peak Expiratory Flow Rates and Respiratory Symptoms of Asthmatics during Asian Dust Periods in Korea." Respirology 10(4), pp. 470-476.

Rosenzweig, M., and T. Schultz. 1982. "Market Opportunities, Genetic Endowments, and Intrafamily Resource Distribution: Child Survival in Rural India," American Economic Review 72(4), pp. 803-15.

Sanders, N. 2012. "What Doesn't Kill You Makes You Weaker: Prenatal Pollution Exposure and Educational Outcomes." Journal of Human Resources 47(3), pp. 826-850.

Zivin, J., and M. Neidell. 2009. "Days of Haze: Environmental Information Disclosure and Intertemporal Avoidance Behavior." Journal of Environmental Economics and Management 58, pp. 119-128.

Zivin, J., M. Neidell, and W. Schlenker. 2011. "Water Quality Violations and Avoidance Behavior: Evidence from Bottled Water Consumption.” American Economic Review 101(3), pp. $448-453$. 